\title{
Respiratory fluxes and fine root responses in mature Picea abies trees exposed to elevated atmospheric $\mathrm{CO}_{2}$ concentrations
}

\author{
Manuel Mildner • Martin Karl-Friedrich Bader • \\ Christina Baumann · Christian Körner
}

Received: 1 June 2014 / Accepted: 15 February 2015/Published online: 21 February 2015

(C) Springer International Publishing Switzerland 2015

\begin{abstract}
With their dominant share in global plant biomass carbon (C), forests and their responses to atmospheric $\mathrm{CO}_{2}$ enrichment are key to the global $\mathrm{C}$ balance. In this free air $\mathrm{CO}_{2}$ enrichment (FACE) study, we assessed respiratory losses from stems and soil, and fine root growth of ca. 110-year-old Picea abies growing in a near-natural forest in NW Switzerland. We anticipated a stimulation of all three variables in response to a ca. $150 \mathrm{ppm}$ higher $\mathrm{CO}_{2}$ concentration in the tree canopies. During the first 2.5 years of the experiment, stem $\mathrm{CO}_{2}$ efflux $\left(R_{\text {stem }}\right)$ remained unresponsive to $\mathrm{CO}_{2}$ enrichment. This indicates that there is no enhancement of metabolic
\end{abstract}

Responsible Editor: W. Troy Baisden.

Electronic supplementary material The online version of this article (doi:10.1007/s10533-015-0084-5) contains supplementary material, which is available to authorized users.

M. Mildner $(\bowtie) \cdot$ M. K.-F. Bader · C. Baumann ·

C. Körner

Institute of Botany, University of Basel,

Schönbeinstrasse 6, 4056 Basel, Switzerland

e-mail: manuel.mildner@unibas.ch

M. K.-F. Bader

New Zealand Forest Research Institute (SCION), Te Papa

Tipu Innovation Park, 49 Sala Street, 3046 Rotorua,

New Zealand

C. Baumann

UTAS AG Büro für Landschaft, Natur und Siedlung,

Brünigstrasse 64, 6074 Giswil, Switzerland activity in phloem and xylem of these mature trees. Soil $\mathrm{CO}_{2}$ efflux $\left(R_{\text {soil }}\right)$ beneath trees experiencing elevated $\mathrm{CO}_{2}\left(\mathrm{eCO}_{2}\right)$ showed a slight but significant reduction compared to $R_{\text {soil }}$ under control trees. High $\mathrm{CO}_{2}$ trees did not increase their fine root biomass in ingrowth cores after 20 months under FACE relative to the fine root fractions collected in undisturbed soil. Tree growth (stem radial increment, not shown here) remained completely unchanged although earlier experiments showed largest responses (if any) during the early years after a step increase in atmospheric $\mathrm{CO}_{2}$ concentration. The data presented here suggest $\mathrm{C}$ saturation of the study trees at the current close to $400 \mathrm{ppm} \mathrm{CO} \mathrm{CO}_{2}$ ambient concentrations. Together with the high local atmospheric $\mathrm{N}$-deposition rates (ca. $20 \mathrm{~kg} \mathrm{~N} \mathrm{ha}^{-1} \mathrm{a}^{-1}$ ), our findings imply that factors other that $\mathrm{C}$ and $\mathrm{N}$ supply appear to constrain growth and metabolism of these mature $P$. abies trees under $\mathrm{eCO}_{2}$.

Keywords Conifers $\cdot$ FACE $\cdot$ Forest $\cdot$ Growth $\cdot$ Soil · Stem · Carbon

\section{Introduction}

The rising levels of atmospheric $\mathrm{CO}_{2}$ are potentially affecting forest biomes not only indirectly via the climatic change, but also directly via potentially enhanced $\mathrm{CO}_{2}$ uptake by tree canopies. Higher leaf- 
level $\mathrm{CO}_{2}$ uptake of forest trees in response to elevated $\mathrm{CO}_{2}\left(\mathrm{eCO}_{2}\right)$ was repeatedly reported (Bader et al. 2010; Darbah et al. 2010; Ellsworth et al. 2012). However, this additional $\mathrm{C}$ uptake mostly resulted in a less-than-anticipated, or no long-term increase in growth or net primary productivity in maturing trees (Körner 2006; Norby and Zak 2011; Leuzinger and Hättenschwiler 2013; Sigurdsson et al. 2013). The direct effect of $\mathrm{CO}_{2}$ via photosynthesis might be masked by a set of counteracting biotic and abiotic effects on tree growth (Körner 2000; Leuzinger and Hättenschwiler 2013). Soil nutrient availability, stand development, and species identity are influencing the potential $\mathrm{CO}_{2}$ fertilization effect (Hättenschwiler et al. 1997; De Graaff et al. 2006; Norby et al. 2010; Bader et al. 2013). The imbalance between increased foliar $C$ uptake without corresponding aboveground growth response to $\mathrm{eCO}_{2}$ might be compensated by a stimulation of fine root growth, or by increased respiratory release of $\mathrm{CO}_{2}$ to the atmosphere.

Although total fine root mass $(<2 \%$ of total tree biomass; Körner 1994) contributes little to ecosystem biomass $\mathrm{C}$-stores $(<1 \%$, including in soil organic matter), the turnover of fine roots provides a significant source for soil humus formation. The rapid turnover of fine roots may, in fact, contribute between 20 and $50 \%$ to annual biomass production (Jackson et al. 2009), and thus, plays a significant role in the global C cycle (Matamala et al. 2003). Some studies on young, expanding systems arrived at ca. $40 \%$ increase in fine root biomass at $\mathrm{eCO}_{2}$ (Curtis and Wang 1998). These results are most likely due to a faster exploration of 'empty' soil when these young trees grew toward canopy closure (unlikely a steadystate signal for mature forests). The Oak Ridge free air $\mathrm{CO}_{2}$ enrichment (FACE) study in a plantation of Liquidambar styraciflua (10-year-old when the study was initiated in 1997) initially reported several years of increased fine root production (Norby et al. 2004), which led to increased $\mathrm{C}$ fluxes to the soil (Jastrow et al. 2005; Iversen et al. 2012). However, this $\mathrm{CO}_{2}$ induced belowground growth stimulation ceased completely towards the end of the 11-year enrichment period, which was explained by the higher nitrogen (N) demand for greater $\mathrm{C}$ uptake (Norby et al. 2010; Garten et al. 2011). Intriguingly, a study with Pinus taeda (Duke FACE; initiated in 1996 with then 13-year-old trees) did not reveal increased soil $\mathrm{C}$ accumulation (Phillips et al. 2012) despite accelerated belowground $\mathrm{C}$ fluxes and higher fine root production belowground (Pritchard et al. 2008; Jackson et al. 2009; Drake et al. 2011). Phillips et al. (2012) highlighted that accelerated microbial activity under $\mathrm{eCO}_{2}$ not only enhances the mineralization of soil organic matter pools (soil priming; Jenkinson et al. 1985) but also offsets the increased input of rootderived $\mathrm{C}$ under $\mathrm{eCO}_{2}$ (rhizodepositions, exudation, and allocation to mycorrhizal fungi) by enhancing the decomposition of these compounds. Similar results were recently obtained in a $\mathrm{CO}_{2}$-enriched scrub-oak community (Hungate et al. 2013). Such priming processes can release additional $\mathrm{N}$, which becomes readily available for tree metabolism (increase $\mathrm{N}$-cycling), and might thus slow the natural, progressive $\mathrm{N}$ limitation (PNL) as forests mature. Additionally, deeper soil exploration by roots under $\mathrm{eCO}_{2}$ might further increase the availability of $\mathrm{N}$ (at least transitorily; Pritchard et al. 2008; Iversen et al. 2011). Stimulated microbial activity also accelerated the returns of $\mathrm{CO}_{2}$ from the soil to the atmosphere in this pine forest (Jackson et al. 2009). $\mathrm{CO}_{2}$-driven priming effects such as described by Phillips et al. (2012) are in accordance with results of the 8-year FACE study on mature deciduous trees growing under near-natural, but $\mathrm{N}$-saturated conditions at our study site (Bader et al. 2013). Here, soil $\mathrm{N}$ availability (Schleppi et al. 2012), and microbial biomass increased significantly under $\mathrm{eCO}_{2}$ (Bader and Körner 2010). However, in contrast to the $P$. taeda results at Duke FACE, no aboveground growth (Bader et al. 2013), no stimulation of soil $\mathrm{CO}_{2}$ efflux (Bader and Körner 2010), and reduced fine root biomass (Bader et al. 2009) were observed in these deciduous trees despite strong photosynthetic stimulation by $\mathrm{eCO}_{2}$ (Bader et al. 2010).

Higher respiratory $\mathrm{CO}_{2}$ release from soils (Drake et al. 2011) would be a consequence of increased belowground $\mathrm{C}$ supply under $\mathrm{eCO}_{2}$ (growth and turnover of roots, rhizodeposition, metabolic activity of roots and mycorrhizal partners), assuming that soil microbes are limited by labile C (Fierer et al. 2009). This might reverse the effect of the often-anticipated $\mathrm{eCO}_{2}$ 'fertilization' on forest ecosystems (Raich and Schlesinger 1992). Higher soil $\mathrm{CO}_{2}$ efflux $\left(R_{\text {soil }}\right)$ under trees exposed to $\mathrm{eCO}_{2}$ has been reported frequently (Spinnler et al. 2002; Bernhardt et al. 2006; Comstedt et al. 2006; Pregitzer et al. 2008; Jackson et al. 2009). However, all these test systems contained young trees 
with expanding root spheres. Not surprisingly, these initial effects declined with time, and were not observed under mature trees in mixed forest stands (Bader and Körner 2010), or in monospecific plantations (King et al. 2004).

Stem $\mathrm{CO}_{2}$ efflux $\left(R_{\text {stem }}\right)$ can contribute $13-42 \%$ to the total aboveground $\mathrm{C}$ budget of trees (Waring and Schlesinger 1985; Hamilton et al. 2002). $R_{\text {stem }}$ responses to $\mathrm{eCO}_{2}$ have mostly been reported in juvenile trees, and they vary considerably (i.e. reductions and increases; Carey et al. 1996; Janouš et al. 2000; Edwards et al. 2002; Hamilton et al. 2002; Zha et al. 2005; Acosta et al. 2010). So far, we do not see any aboveground growth stimulation following $\mathrm{CO}_{2}$ enrichment in the tall trees examined here (T. Klein and C. Körner, unpublished), despite indications of increased leaf-level $\mathrm{C}$ uptake under $\mathrm{eCO}_{2}$ (Leuzinger and Bader 2012; Bader et al., in prep.; T. Klein, pers. comm.). Therefore, any $\mathrm{CO}_{2}$-driven stimulation of $R_{\text {stem }}$ would reflect higher phloem activity or maintenance respiration, or a signal resulting from enhanced $\mathrm{CO}_{2}$ release in the rhizosphere, from where the respiratory $\mathrm{C}$ may find its way into $R_{\text {stem }}$ via the xylem sap.

We used the Swiss Canopy Crane (SCC) webFACE facility (Pepin and Körner 2002) to expose the canopies of 37-m tall, and ca. 110-year-old $P$. abies to increased levels of atmospheric $\mathrm{CO}_{2}$. The effectiveness of $\mathrm{CO}_{2}$ enrichment could be confirmed by $\mathrm{C}$ isotope signals (Mildner et al. 2014). Here we report the initial responses (i.e. the first 2.5 years of FACE) of $P$. abies to atmospheric $\mathrm{CO}_{2}$ enrichment, with a focus on stem and soil $\mathrm{CO}_{2}$ release, and fine root production. We hypothesized (i) a stimulation in fine root production, (ii) enhanced $\mathrm{CO}_{2}$ efflux from soils, and (iii) greater stem $\mathrm{CO}_{2}$ efflux under $\mathrm{eCO}_{2}$ compared to ambient conditions.

\section{Materials and methods}

Study site and experimental setup

The experiment was established in a highly diverse, near-natural forest $12 \mathrm{~km}$ south-west of Basel, Switzerland $\left(47^{\circ} 33^{\prime} \mathrm{N}, 7^{\circ} 36^{\prime} \mathrm{E}, 500 \mathrm{~m}\right.$ a.s.l), dominated by ca. 100-120-year-old deciduous and coniferous trees (dominant species are i.e. Fagus sylvatica L., Quercus petraea (Matt.) Liebl., Carpinus betulus L., Picea abies (L.) Karst., Larix decidua Mill., Pinus sylvestris L.,
Abies alba Mill.; Fig. S4). The site has a mild temperate climate, with seasonal mean temperatures (MaySeptember) of $14.7^{\circ} \mathrm{C}$, and ca. $800 \mathrm{~mm} \mathrm{a}^{-1}$ precipitation (Bader and Körner 2010). In 2009, five $37 \mathrm{~m}$ tall, 110-year-old Norway spruce ( $P$. abies) individuals were equipped with an improved web-FACE system (Pepin and Körner 2002; Körner et al. 2005; Mildner et al. 2014) using a $45 \mathrm{~m}$ tall canopy crane. $\mathrm{CO}_{2}$ was released into the tree canopies through non-invasive laser-punched tubes (4 $\mathrm{mm}$ diameter) woven around the tree branches, allowing for computer-controlled adjustment of the $\mathrm{CO}_{2}$ release with regard to wind direction by employing sectional control of $\mathrm{CO}_{2}$. The web-FACE technique applied here provided the best possible means to enrich mature $P$. abies trees with additional $\mathrm{CO}_{2}$ given the tree height, and the complexity of the conditions on-site. Those limitations of the web-FACE technique have been discussed in more detail elsewhere (see Pepin and Körner 2002). Our system showed good spatio-temporal performance (Leuzinger, pers. comm.). Median $\mathrm{CO}_{2}$ concentrations were between 500 and $560 \mathrm{ppm}$ in the canopies (60 sampling points per IRGA reading), with means of 541, 532, and 541 ppm for 2009, 2010, and 2011, respectively (Mildner et al. 2014). We discontinued the FACE treatment if either temperatures were below $4{ }^{\circ} \mathrm{C}$, PPFD was $<100 \mu \mathrm{mol}$, or wind was above $10 \mathrm{~m} \mathrm{~s}^{-1}$. So, FACE was largely off during the coldest period from early November until early March (4 months). $\mathrm{CO}_{2}$ enrichment started on 30 July 2009. Only the tree canopy between 15 and $37 \mathrm{~m}$ aboveground was $\mathrm{CO}_{2}$-enriched, with no downward flow, preventing uncontrolled ' $\mathrm{CO}_{2}$ pollution' of the understory vegetation and soil surface. Since the $\mathrm{CO}_{2}$ employed for canopy enrichment carries a constant ${ }^{13} \mathrm{C}$ isotope signal $\left(\delta^{13} \mathrm{C}-30 \%\right.$ ), it was possible to trace the carbon flows in trees and soils. Together with IRGA-based monitoring of $\mathrm{CO}_{2}$ concentrations in the canopy air, this isotopic $\mathrm{C}$ tracing allowed us to assess the effectiveness of the web-FACE system, and to show that there was no contamination of the control trees by extra $\mathrm{CO}_{2}$ (Mildner et al. 2014). The $\mathrm{CO}_{2^{-}}$ treated trees $\left(\mathrm{eCO}_{2}\right.$-trees) formed a group, facilitating $\mathrm{CO}_{2}$ enrichment and clear association of signals with investigated trees (Fig. S4). Five similarly tall trees under ambient $\mathrm{CO}_{2}\left(\mathrm{aCO}_{2}\right)$, away from the treated trees, served as controls $\left(\mathrm{aCO}_{2}\right.$-trees). All but one of these $\mathrm{aCO}_{2}$-trees were outside the perimeter of the crane's jib. 
Climate variables

Hourly temperatures at different heights $(10 \mathrm{~cm}$ belowground, $\mathrm{T}_{\text {soil }}$; at the soil surface in the litter layer, $\mathrm{T}_{\text {litter }} ; 2 \mathrm{~m}$ aboveground, $\mathrm{T}_{\text {air }}$ ) were recorded next to an $\mathrm{eCO}_{2}$-tree using a temperature data logger (HOBO TidbiT v2; Onset Computer Corp., Bourne, MA, USA). Technical failure caused incomplete datasets that could not be complemented by statistical interpolation (see Fig. 1). Starting in August 2008 (a year before FACE), soil moisture (vol. \%) at $0-10 \mathrm{~cm}$ depth was recorded every $6 \mathrm{~h}$ around the investigated trees (11 and 18 sensors arranged around the $\mathrm{eCO}_{2}$ and $\mathrm{aCO}_{2}$-trees, respectively) using soil moisture probes, connected to a self-contained data logger (10HS and EM50, Decagon Devices Ltd., Pullman, Washington, DC, USA). Precipitation was recorded every $2 \mathrm{~min}$, provided by a weather station situated $2 \mathrm{~km}$ from the SCC site (Flüh, Solothurn, Switzerland). Precipitation was summed on a daily basis.
Fine root sampling

On 24 March 2010, 8 months after the onset of FACE, or 4 months of effective canopy $\mathrm{CO}_{2}$ enrichment, we took 9 soil cores $(12 \mathrm{~cm}$ in depth $\times 3.6 \mathrm{~cm}$ diameter $)$ per tree in the main rooting sphere $(2 \mathrm{~m}$ around the tree trunks) to ensure that we captured the fine roots of $P$. abies. The 9 soil cores were organized into three groups of three soil cores (triplets). The triplets were placed at an angle of $120^{\circ}$ around each trunk, with $10 \mathrm{~cm}$ distance between each soil core in a triplet. The fine root biomass found in the soil cores was averaged per tree to account for microscale heterogeneity. We used these coring holes to install equally sized in-growth cores (cylinders made of a $2 \mathrm{~mm}$ stiff mesh), filled with sieved, root-free soil collected on-site. The soil in the in-growth cores was gently compacted to match the in situ bulk soil density (mass to volume ratio). The in-growth cores were extracted 20 months later (6 December 2011) by means of a knife. The soil and in-growth cores were kept frozen

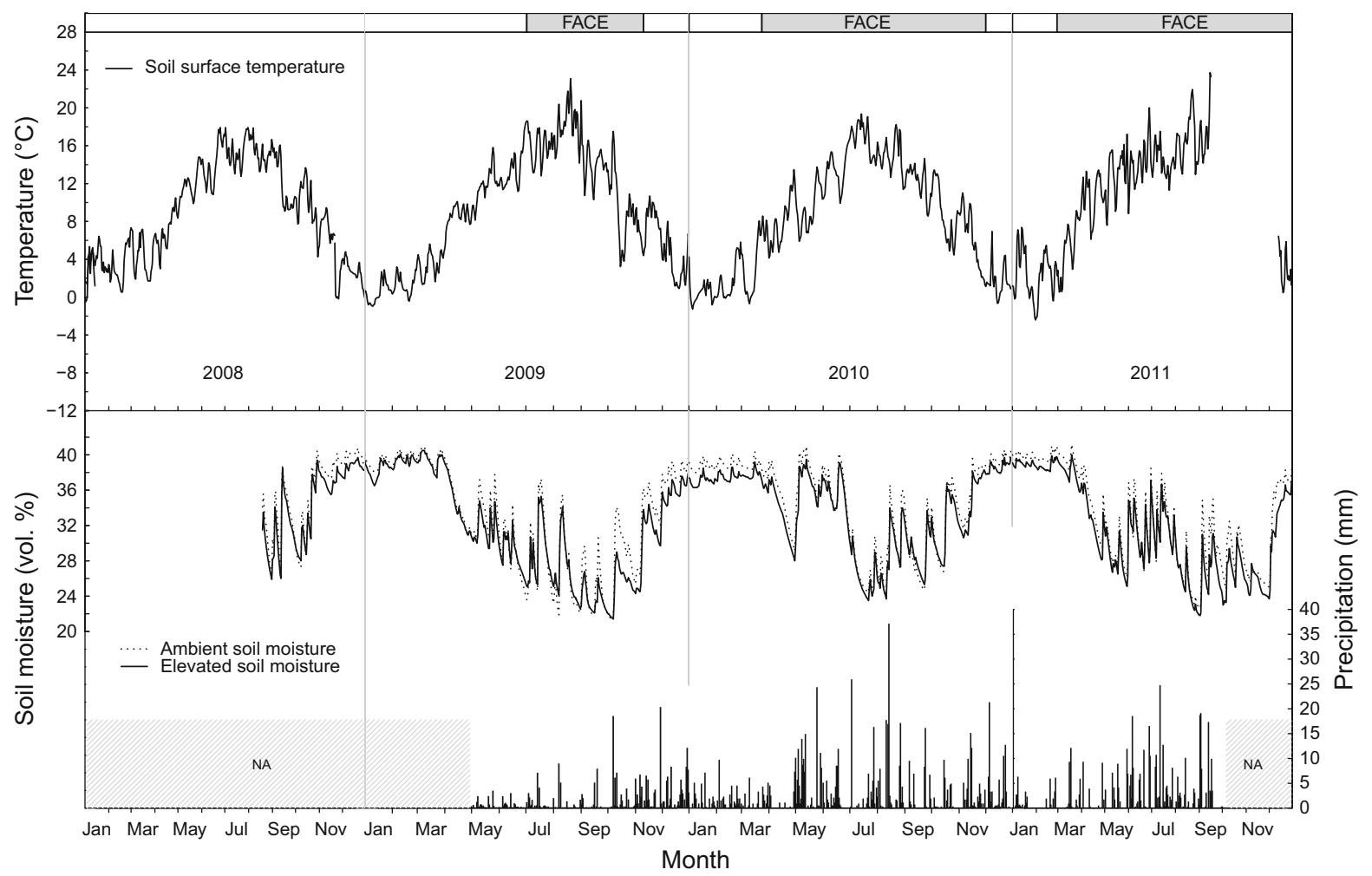

Fig. 1 Seasonal variation of daily soil surface $\mathrm{T}$ under litter (solid black line in the upper four panels), precipitation (vertical bars), and soil moisture in the top $10 \mathrm{~cm}$ (lower four panels) measured either at the swiss canopy crane (SCC) site (T and soil moisture), or taken from a nearby weather station $2 \mathrm{~km}$ away from the SCC site (precipitation) in the years 2008 to 2011 (left to right). Soil moisture was measured either under control Picea abies trees (dashed line), or under $\mathrm{CO}_{2}$ treated trees (solid line) 
at $-20{ }^{\circ} \mathrm{C}$ until further analysis. The cores were defrosted in cold water for $48 \mathrm{~h}$ at $4{ }^{\circ} \mathrm{C}$ before processing to slow microbial degradation of fine roots. Fine roots were extracted using a sieve (1 mm mesh) and tweezers. P. abies fine roots were selected on the basis of a $P$. abies reference root collection. The distinct morphology of $P$. abies roots warranted the separation of $P$. abies roots from roots of other species (as later confirmed by $\delta^{13} \mathrm{C}$ signals; Mildner et al. 2014). We did not quantify the fraction of non-P. abies fine roots at the time of harvest. However, we revisited the fine root fraction matter and re-sampled the same location, and weighed the non- $P$. abies fine root fraction in autumn 2014. We found that half of the fine roots were from $P$. abies, and the other half belonged to the surrounding trees of this semi-natural mixed forest. Fine roots were classified into three diameter classes $(<0.5,0.5-1$, 1-2 mm), dried at $80{ }^{\circ} \mathrm{C}$ for $48 \mathrm{~h}$, and weighed for biomass determination. No differentiation of still intact dead and live fine roots was made.

\section{Soil respiration}

We measured $\mathrm{CO}_{2}$ release from the forest floor, hereafter referred to as soil respiration $\left(R_{\text {soil }} ; \mu \mathrm{mol}\right.$ $\mathrm{CO}_{2} \mathrm{~m}^{-2} \mathrm{~s}^{-1}$ ), with two identical custom-made, closed, non-steady-state, non-through-flow chambers. The chambers were equipped with open path, non-dispersive infrared gas analysers, and relative humidity/T sensors (GMP343 carbon dioxide probe, HMP75 rH/T probe; Vaisala, Vantaa, Finland; detailed description of the system in Bader and Körner 2010). Polypropylene collars (Ø 20, 5-7 cm height), inserted ca. 2-3 cm into the soil, served as a socket and seal for the chambers. We installed three collars per tree in $2 \mathrm{~m}$ distance to the stem base at a $120^{\circ}$ angle around each tree, serving as replicates for each tree. These collars were left in place throughout the course of the experiment. Photosynthetically active tissue inside the collars (very minor understorey herbs) was removed prior to $R_{\text {soil }}$ measurements, but litter was left in place to ensure natural conditions. Monthly measurements started in July 2008, 1 year before FACE initiation, and were intensified after the onset of FACE on 30 July 2009. During winter, measurements were suspended when snow covered the ground. Chamber recordings were performed at maximum daytime $R_{\text {soil }}$ rates (i.e. from 1 to $6 \mathrm{pm}$ ), alternating between $\mathrm{eCO}_{2}$ - and $\mathrm{aCO}_{2}$-trees to reduce any temporal bias. $R_{\text {soil }}$ rates were calculated by applying a linear regression to the increase of the $\mathrm{CO}_{2}$ concentration inside the chamber headspace over $4 \mathrm{~min}$ (60 recordings per $5 \mathrm{~min}$, the first minute of each measurement were discarded to account for potential chamber placement effects). Soil temperature at $10 \mathrm{~cm}$ soil depth $\left(\mathrm{T}_{\text {soil }}\right)$ was recorded simultaneously adjacent to the collars using a KM20REF thermometer (Comark, Instruments, Norwich, UK).

\section{Stem respiration}

Stem $\mathrm{CO}_{2}$ release, hereafter referred to as stem respiration $\left(R_{\text {stem }} ; \mu \mathrm{mol} \mathrm{CO} \mathrm{Cm}^{-2} \mathrm{~s}^{-1}\right)$, was measured using the LI-COR 6400-09 Soil $\mathrm{CO}_{2}$ Flux Chamber connected to a LI-6400XT Portable Photosynthesis System (LI-COR, Lincoln, Nebraska, USA). The soil chamber operated in a closed system mode, and $\mathrm{CO}_{2}$ drawdown inside the headspace allowed us to measure multiple cycles. We recorded 2-3 cycles per measurement and calculated the average. Four circular polyethylene collars ( $\varnothing 10,4-5 \mathrm{~cm}$ high) were attached to the stem surface of each tree at ca. $1.3 \mathrm{~m}$ above ground, facing the cardinal directions (N, E, S, W). We used hot-melt adhesive and sealent (Terostat-IX, Teroson, Ludwigsburg, Germany) to ensure airtight collar connection to the stem surface. These collars served as chamber sockets. We did not install $\mathrm{T}$ sensors inside the stem sapwood. Thus, air temperature measured directly on the bark $\left(\mathrm{T}_{\text {bark }}\right)$ served as temperature reference using the LI-COR 6000-09TC Soil Probe Thermocouple (LI-COR, Lincoln, Nebraska, USA). We started measurements prior to the start of FACE (pre-treatment). We regarded $R_{\text {stem }}$ signals 7 days after the onset of FACE as pre-treatment signals since the lag between leaf-level C assimilation and signal detection in $R_{\text {stem }}$ is ca. 12 days (Mildner et al. 2014). Measurements were taken in 1-3 month intervals in 2009 and 2010, with two final measurements early in 2011.

\section{Data analysis}

The $\mathrm{T}$ dependency of respiratory fluxes (soil and stem) was modeled using a nonlinear least squares regression following Lloyd and Taylor (1994):

$R=R_{10} e^{\mathrm{E}_{\mathrm{o}}\left(\frac{1}{56.02}-\frac{1}{\mathrm{~T}-227.13}\right)}$,

where $R$ is the measured respiration rate (either $R_{\text {soil }}$ or $\left.R_{\text {stem }}\right)$ and $R_{10}$ the respiration rate at $10{ }^{\circ} \mathrm{C}\left(\mathrm{T}_{\text {soil }}\right.$ for 
soil respiration, and $\mathrm{T}_{\text {bark }}$ for stem respiration), $E_{\mathrm{O}}$ is the activation energy. The Lloyd and Taylor (LT) approach outperforms conventional $R$ versus T correlation models (Arrhenius, van't Hoff). The T sensitivity of $R_{\text {soil }}$ or $R_{\text {stem }}\left(Q_{10}\right)$ was modeled following:

$Q_{10}=\left(\frac{R_{2}}{R_{1}}\right)^{\left(\frac{10^{\circ} C}{T 2-T 1}\right)}$,

where $R_{1}$ and $R_{2}$ are the respiration rates at temperatures of $10{ }^{\circ} \mathrm{C}\left(T_{1}\right)$ and $20{ }^{\circ} \mathrm{C}\left(T_{2}\right)$ (at $10 \mathrm{~cm}$ soil depth or at the bark surface), respectively, derived from the modeled LT regression. Pre-treatment differences in $R_{\text {soil }}$ between trees later exposed to $\mathrm{eCO}_{2}$ and $\mathrm{aCO}_{2}$ were accounted for by assigning a temperature dependent correction factor to $R_{\text {soil }}$ of $\mathrm{eCO}_{2}$-trees in the FACE period. This correction factor was calculated from the difference of the modeled LT curves (Eq. 1) between $\mathrm{eCO}_{2}$ and $\mathrm{aCO}_{2}$ during the pre-treatment years (2008 and 2009). However, since the pre-treatment data for $R_{\text {stem }}$ did not allow for modeling a $\mathrm{R}$ versus $\mathrm{T}$ relationship (insufficient T range), $R_{\text {stem }}$ of $\mathrm{eCO}_{2}$-trees in the FACE period was standardized by the mean pretreatment $\mathrm{aCO}_{2} / \mathrm{eCO}_{2}$ difference, thus assuming that the T response of $R_{\text {stem }}$ did not change. These corrected respiratory fluxes were used to model the LT regression of $\mathrm{eCO}_{2}$-trees under FACE (Eq. 1), and further parameters $\left(Q_{10}, R_{10}\right.$; Eq. 2). Confidence limits for the modeled $Q_{10}$ and $R_{10}$ values were obtained from bootstrapped $95 \%$ confidence intervals. Annual release of $\mathrm{C}$ by stems, or soil, respectively, was calculated based upon the modeled LT regression (Eq. 1) by summing the estimated hourly $R$ rates from continuously logged temperatures for all investigated years. We used either hourly records of $\mathrm{T}_{\text {air }}$ to calculate the annual $\mathrm{C}$ release by stems, or continuously available groundlitter (soil surface) temperature, correlating well with $\mathrm{T}_{\text {soil }}$ to calculate annual $\mathrm{C}$ release by the soil (missing values in the second half of 2011 were reconstructed from $\mathrm{T}_{\text {air }}$; see Fig. 1). We know that the T response of $R_{\text {soil }}$ does not differ between day and night based on diurnal respiration measurements (Bader et al. in prep.). Data analysis was performed using the software R, version 2.15.0 (R Development Core Team 2011).

\section{Statistical analysis}

Linear mixed effects models fitted by restricted maximum likelihood were applied in all statistical analyses using $\mathrm{R}$, version 2.15.0 ( $\mathrm{R}$ Development Core Team 2011; R package nlme). The replicated unit in this project was a single 'tree' (five control trees under $\mathrm{aCO}_{2}$, and five trees subjected to $\mathrm{eCO}_{2}$ ). Therefore, all measurements per tree were averaged prior to analysis. Since both groups of trees were studied before FACE and after the onset of FACE, we defined a 'pretreatment' factor to account for any change that might have occurred between the pre-treatment and FACE period. We assessed the significance of the main effects using a backwards selection procedure that progressively removes all non-significant terms until the optimal model is attained. This means that all terms not contained in the final model were statistically not significant. Model selection was validated by likelihood ratio tests and the akaike information criterion. The random factor'tree' was included in all models. Where necessary, homogeneity violations were modeled using adequate variance function structures (power, constant power, exponential and constant variance structures, or a combination thereof), and independence violations were corrected by implementing temporal autocorrelation structures. Model assumptions were examined using diagnostic plots (i.e. residual and quantile-quantile plots).

\section{Results}

\section{Climatic conditions}

Annual $\mathrm{T}_{\text {air }}$ averaged $8.2^{\circ} \mathrm{C}$ in 2010 (min. -8.6, and max. $24.4{ }^{\circ} \mathrm{C}$ ), and at $10.1{ }^{\circ} \mathrm{C}$ in 2011 (min. -5.7, and $\left.\max .25 .2{ }^{\circ} \mathrm{C}\right)$. The mean $\mathrm{T}_{\text {litter }}$ was $9.1{ }^{\circ} \mathrm{C}(\min .-1.0$, and max. $23.1{ }^{\circ} \mathrm{C}$ ), and $8.1{ }^{\circ} \mathrm{C}$ (min. -1.3 , and max. $19.4{ }^{\circ} \mathrm{C}$ ) for 2009 and 2010, respectively. We fitted linear regression models with $\mathrm{T}_{\text {litter }}$ as response variable, and either $\mathrm{T}_{\text {air }}$ or $\mathrm{T}_{\text {soil }}$ as predictors. The amount of explained variation seen in $\mathrm{T}_{\text {litter }}$ increased when $\mathrm{T}_{\text {soil }}$ was used instead of $\mathrm{T}_{\text {air }}$. This is reflected in the lower $\mathrm{R}^{2}$ between $\mathrm{T}_{\text {litter }}$ and $\mathrm{T}_{\text {air }}\left(R^{2}=0.841\right)$ compared to $\mathrm{T}_{\text {litter }}$ and $\mathrm{T}_{\text {soil }}\left(R^{2}=0.967\right)$. The $\mathrm{T}_{\text {soil }}$ record had some gaps so that $\mathrm{T}_{\text {litter }}$ could be used for $\mathrm{T}_{\text {soil }}$. Given the strong correlation between $\mathrm{T}_{\text {soil }}$ and $\mathrm{T}_{\text {litter }}$, we only show $\mathrm{T}_{\text {litter }}$ (Fig. 1). Precipitation was normal during the study period (no exceptionally dry period; for daily precipitation records see Fig. 1). Soil moisture was always high and tended to be slightly lower $\left(-1.1\right.$ vol. \%) under the $\mathrm{CO}_{2}$-treated spruce 
trees compared to control trees before FACE (Fig. 1). This pattern did not change over the course of this experiment (Leuzinger and Bader 2012).

\section{Tree fine root biomass}

Irrespective of the later ongoing treatment $\left(\mathrm{eCO}_{2}\right.$ or $\mathrm{aCO}_{2}$ ), there was significantly more biomass in the finest root fraction (78 $\pm 8 \mathrm{~g} \mathrm{~m}^{-2}$ in $<0.5 \mathrm{~mm}$ ) compared to the biomass of $0.5-2 \mathrm{~mm}$ fine roots $\left(18 \pm 3 \mathrm{~g} \mathrm{~m}^{-2}\right)$ collected in late March 2010 after only three months of late season $\mathrm{CO}_{2}$-enrichment ('Diameter' effect: $P<0.001$; Table 2; Fig. 2). These amounts of fine roots, collected from undisturbed soil, are supposed to depict the initial steady-state situation for this forest. Total fine root biomass (all diameter classes combined) of $\mathrm{eCO}_{2}$-trees and $\mathrm{aCO}_{2}$-trees did not differ (115 vs. $112 \mathrm{~g} \mathrm{~m}^{-2}$; no 'site' effect; $P=0.211$; Table 2). However, we determined $27 \%$ lower fine root biomass under $\mathrm{COO}_{2}$ compared to $\mathrm{aCO}_{2}$ in the $<0.5 \mathrm{~mm}$ diameter class $\left(99 \pm 17\right.$ vs. $\left.135 \pm 10 \mathrm{~g} \mathrm{~m}^{-2}\right)$, whereas there was $29-61 \%$ higher biomass under $\mathrm{eCO}_{2}$ relative to $\mathrm{aCO}_{2}$ in the $0.5-1 \mathrm{~mm}\left(51 \pm 8\right.$ vs. $\left.39 \pm 4 \mathrm{~g} \mathrm{~m}^{-2}\right)$, and

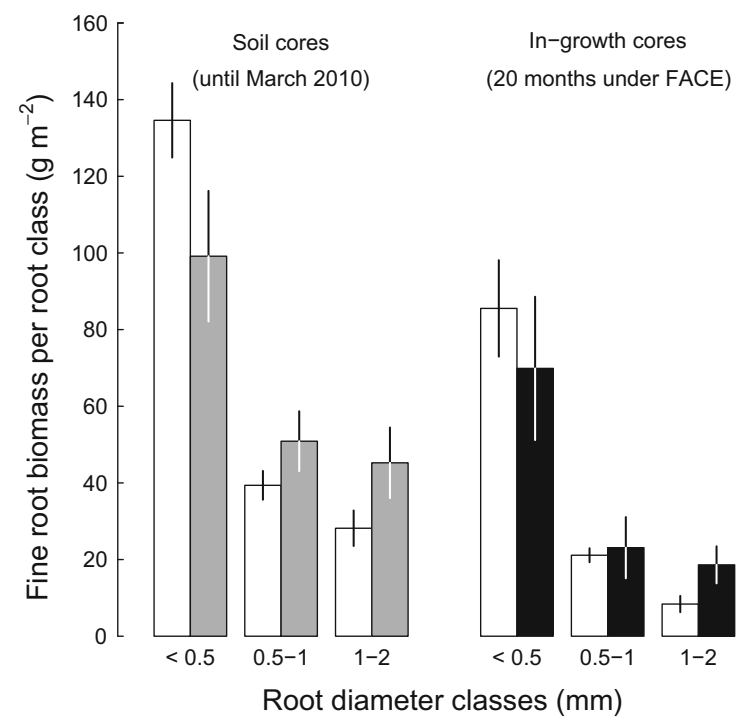

Fig. 2 Fine root biomass under Picea abies trees. White bars indicate data from trees exposed to ambient $\mathrm{CO}_{2}$, and grey bars specify initial root data for trees exposed to elevated $\mathrm{CO}_{2}$ (in situ content of boreholes later used for in-growth cores), black bars show the fine roots accumulated in in-growth cores after 20 months (ambient $\mathrm{CO}_{2}: n=5$ trees, elevated $\mathrm{CO}_{2}: n=5$ trees, mean \pm SE). Left panel, fine roots in soil cores sampled at the beginning of the experiment. Right panel, fine roots in ingrowth cores after 20 months of FACE
1-2 mm (45 \pm 9 vs. $\left.28 \pm 5 \mathrm{~g} \mathrm{~m}^{-2}\right)$ categories at the start of the experiment (significant 'root thickness $\times$ site' interaction at $P=0.001$; Table 2; Fig. 2).

Generally, there was a high proportionality between in-growth fine root mass and initial mass under in situ conditions (soil cores). The $<0.5 \mathrm{~mm}$ diameter category had far more fine root biomass than the 0.5-2 mm classes $\left(117 \pm 18\right.$ vs. $41 \pm 5 \mathrm{~g} \mathrm{~m}^{-2} ; \quad P<0.001 ;$ Table 2 ; Fig. 2). Overall, fine roots (all diameter categories combined) expanding into root-free soil exclusively during FACE (in-growth cores) produced similar biomass under $\mathrm{eCO}_{2}$ and $\mathrm{aCO}_{2}$ (202 vs. $195 \mathrm{~g} \mathrm{~m}^{-2}$ under $\mathrm{eCO}_{2}$ relative to $\mathrm{aCO}_{2} ; P=0.575$; Table 2). However, similar to the soil cores, the in-growth cores showed more fine root biomass under $\mathrm{eCO}_{2}$ relative to $\mathrm{aCO}_{2}$ in the $0.5-1$ and $1-2 \mathrm{~mm}$ diameter fractions $(0.5-1 \mathrm{~mm}$ : $23 \pm 8$ vs. $21 \pm 2 \mathrm{~g} \mathrm{~m}^{-2} ; \quad 1-2 \mathrm{~mm}: 19 \pm 5$ vs. $8 \pm 2 \mathrm{~g} \mathrm{~m}^{-2}$; Fig. 2). Yet, in the $<0.5 \mathrm{~mm}$ root fraction we found $18 \%$ lower fine root biomass in $\mathrm{eCO}_{2}$-trees relative to $\mathrm{aCO}_{2}$-trees $\left(70 \pm 19\right.$ vs. $86 \pm 13 \mathrm{~g} \mathrm{~m}^{-2}$; Fig. 2), which was again similar to the initial pattern seen in undisturbed soil cores ('Diameter $\times \mathrm{CO}_{2}$ ' effect: $P=0.036$; Table 2). Irrespective of the $\mathrm{CO}_{2}$ treatment and diameter class, fine root dry mass in in-growth cores $\left(227 \mathrm{~g} \mathrm{~m}^{-2}\right.$ ) arrived at only $57 \%$ of the fine root mass previously found in soil cores $\left(397 \mathrm{~g} \mathrm{~m}^{-2}\right.$; Fig. 2). This finding suggests that the soil space in in-growth cores was not fully explored after 20 months under FACE.

\section{Soil respiration}

Pre-treatment measurements (all records collected during the 12 months before the start of FACE on 30 July 2009) revealed $0.6 \pm 0.1 \mu \mathrm{mol} \mathrm{CO} \mathrm{CO}_{2} \mathrm{~m}^{-2} \mathrm{~s}^{-1}$ higher $R_{\text {soil }}$ rates under later $\mathrm{eCO}_{2}$-trees compared to $\mathrm{aCO}_{2^{-}}$ trees $\left(3.5 \pm 0.2\right.$ vs. $2.9 \pm 0.2 \mu \mathrm{mol} \mathrm{CO} \mathrm{Cm}^{-2} \mathrm{~s}^{-1}$ in later $\mathrm{eCO}_{2}$-trees vs. $\mathrm{aCO}_{2}$-trees; Fig. S1). A trend towards slightly lower rates of $R_{\text {soil }}$ under $\mathrm{eCO}_{2}$ relative to $\mathrm{aCO}_{2}$ was observed when standardizing $R_{\text {soil }}$ of $\mathrm{eCO}_{2^{-}}$ trees during FACE by the T-dependent difference during the pre-treatment years (reduction of $0.2 \pm 0.1 \mu \mathrm{mol}$ $\mathrm{CO}_{2} \mathrm{~m}^{-2} \mathrm{~s}^{-1}$ in 2010 , and $0.3 \pm 0.1 \mu \mathrm{mol} \mathrm{CO} \mathrm{m}^{-2} \mathrm{~s}^{-1}$ in 2011; mean \pm SE; Fig. 3). This corresponds to $90 \pm 4$ and $86 \pm 3 \%$ of $R_{\text {soil }}$ under $\mathrm{aCO}_{2}$ in 2010 and 2011, respectively. The annual mean of $R_{\text {soil }}$ of $\mathrm{aCO}_{2}$-trees was $2.4 \pm 0.1 \quad$ (2009), $2.1 \pm 0.1 \quad$ (2010), and $2.2 \pm 0.1 \mu \mathrm{mol} \mathrm{CO} \mathrm{m}^{-2} \mathrm{~s}^{-1}$ (2011), whereas $R_{\text {soil }}$ of $\mathrm{eCO}_{2}$-trees averaged at $2.3 \pm 0.1$ (2009), $1.9 \pm 0.1$ (2010), and $2.0 \pm 0.1 \mu \mathrm{mol} \mathrm{CO}_{2} \mathrm{~m}^{-2} \mathrm{~s}^{-1}$ (2011). 


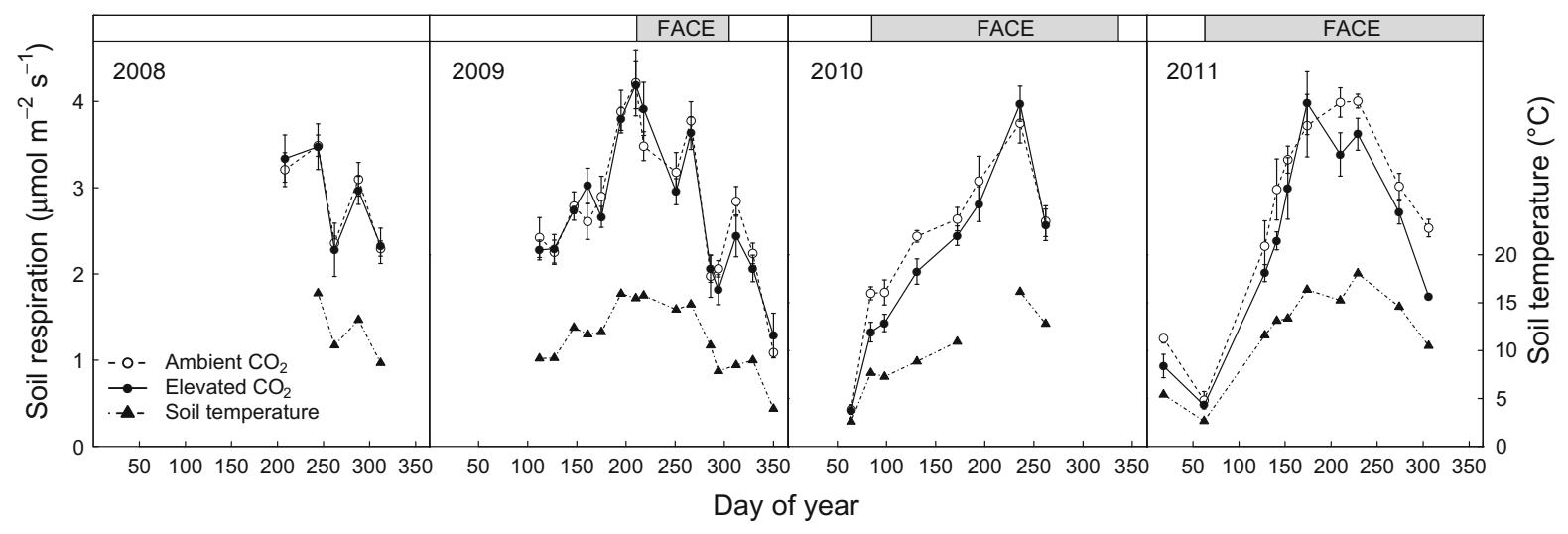

Fig. 3 Soil respiration $\left(R_{\text {soil }}\right)$ and soil temperature at $10 \mathrm{~cm}$ depth of mature Picea abies exposed to ambient, or elevated atmospheric $\mathrm{CO}_{2}$ concentrations in 2008, 2009, 2010, and 2011 (ambient $\mathrm{CO}_{2}: n=5$ trees; elevated $\mathrm{CO}_{2}: n=5$ trees; mean $\pm \mathrm{SE})$. $R_{\text {soil }}$ of trees exposed to elevated $\mathrm{CO}_{2}$ was

Hence, the significant main ' $\mathrm{CO}_{2}$ ' effect $(P=0.025$; Table 2), and the ' $\mathrm{CO}_{2} \times$ pre-treatment' interaction $(P<0.001)$ indicate that the pattern observed before the initiation of FACE differed significantly from the pattern observed after the onset of FACE, with significantly lower $R_{\text {soil }}$ under $\mathrm{eCO}_{2}$-trees relative to $\mathrm{aCO}_{2}$-trees. Also the cumulative annual $\mathrm{C}$ release was lower under $\mathrm{eCO}_{2}$-trees (Fig. 5; Table 1). During the pre-treatment period, designated $\mathrm{eCO}_{2}$-trees showed 19-23\% higher annual $R_{\text {soil }}$ but, after correcting for the pre-treatment differences, this signal reversed, resulting in $8-11 \%$ lower levels during the FACE periods in 2010-2011 after correcting for the pre-treatment differences (Fig. S3; Fig. 5; Table 1). $R_{\text {soil }}$ revealed a distinct seasonality that was determined by the seasonal course of $\mathrm{T}_{\text {soil }} . \mathrm{T}_{\text {soil }}$ explained 38-88\% of the variation in $R_{\text {soil }}$ ( $P<0.001$; Fig. 3; Tables 1,2$)$. Maximum $R_{\text {soil }}$ was measured in July 2009 just before the onset of FACE $\left(\mathrm{eCO}_{2}: 4.2 \pm 0\right.$; and $\mathrm{aCO}_{2}: 4.2 \pm 0.2 \mu \mathrm{mol} \quad \mathrm{CO}_{2}$ $\mathrm{m}^{-2} \mathrm{~s}^{-1}$ at a $\mathrm{T}_{\text {soil }}$ of c. $\left.16^{\circ} \mathrm{C}\right)$. Soil moisture influenced $R_{\text {soil }}$ only in interaction with $\mathrm{T}_{\text {soil }}(P=0.036)$. The statistically insignificant two-way interactions $\left(\mathrm{CO}_{2} \times \mathrm{T}_{\text {soil }} P=0.114 ; \mathrm{CO}_{2} \times\right.$ soil moisture $P=$ 0.287 ; Table 2) indicate that the observed $\mathrm{CO}_{2}$ enrichment effect was independent of these parameters.

\section{Stem respiration}

Instantaneous mid-summer rates of $R_{\text {stem }}$ were $4.5 \pm 0.2$ and $3.5 \pm 0.3 \mu \mathrm{mol} \mathrm{CO} \mathrm{Cm}^{-2} \mathrm{~s}^{-1}$ in later $\mathrm{eCO}_{2}$-trees and in $\mathrm{aCO}_{2}$-trees, respectively, before the corrected for the pre-treatment difference observed between control and treated trees (see materials and methods). Soil temperature under elevated and ambient $\mathrm{CO}_{2}$ did not differ (n.s.). Therefore, the mean of all trees is plotted $(n=10)$. The grey-shaded areas on top of the panels denote the FACE periods

FACE treatment became effective (Fig. S2). Thus, $R_{\text {stem }}$ in designated $\mathrm{eCO}_{2}$-trees was $1.0 \mu \mathrm{mol} \mathrm{CO}_{2}$ $\mathrm{m}^{-2} \mathrm{~s}^{-1}$ higher relative to $\mathrm{aCO}_{2}$-trees during this period of peak $R_{\text {stem }}$ (a $29 \%$ higher signal; Fig. S2). Since $\mathrm{T}_{\text {bark }}$ was similar among the treatments, the different rates of $R_{\text {stem }}$ observed before FACE initiation reflects tree-specific differences (Fig. S2; Fig. S3). Accounting for this pre-treatment difference, $R_{\text {stem }}$ of $\mathrm{eCO}_{2}$-trees was slightly but not significantly $\left(0.1 \pm 0.1 \mu \mathrm{mol} \mathrm{CO} \mathrm{CO}^{-2} \mathrm{~s}^{-1}\right)$ lower than in $\mathrm{aCO}_{2^{-}}$ trees across all years under FACE (mean \pm SE of $R_{\text {stem }}$ in $\mathrm{eCO}_{2}$-trees and $\mathrm{aCO}_{2}$-trees, respectively: $1.8 \pm 0.4$ and $1.9 \pm 0.4 \mu \mathrm{mol} \mathrm{CO}_{2} \mathrm{~m}^{-2} \mathrm{~s}^{-1}$; Table 2; Fig. 4). The mean $Q_{10}$ for 2010 was 1.9 for both treated and control trees $\left(95 \% \mathrm{CI}: 1.5-2.3\right.$ for $\mathrm{eCO}_{2-}$ trees, and 1.6-2.3 for $\mathrm{aCO}_{2}$-trees; Fig. 5; Fig. S3; Table 1). $Q_{10}$ data for 2009 and 2011 suffered from insufficient sample size (large $95 \%$ CI; Table 1). Accounting for the ca. $29 \%$ higher peak season pretreatment signal under $\mathrm{eCO}_{2}$ compared to $\mathrm{aCO}_{2}$ (Fig. $\mathrm{S} 2$ ), the cumulative $\mathrm{C}$ release from stems over the year 2009 was similar (4\% higher) under $\mathrm{eCO}_{2}$ compared to $\mathrm{aCO}_{2}$ (n.s.). During $\mathrm{FACE}, \mathrm{eCO}_{2}$-trees respired less than $\mathrm{aCO}_{2}$-trees $(-7 \%$ in 2010 , and $-14 \%$ in 2011; Table 1). Irrespective of the $\mathrm{CO}_{2}$ treatment, $R_{\text {stem }}$ correlated with $\mathrm{T}_{\text {bark }}(P<0.001)$, accounting for 60-81\% of the seasonal variation in $R_{\text {stem }}$ (Table 1 ). Accordingly, $R_{\text {stem }}$ peaked in late summer and coincided with highest $\mathrm{T}_{\text {bark }}\left(\mathrm{eCO}_{2}: 4.0 \pm 0.6 \mu \mathrm{mol} \mathrm{CO}_{2}\right.$ $\mathrm{m}^{-2}$ at $29.2{ }^{\circ} \mathrm{C}$, and $\mathrm{aCO}_{2}: 4.4 \pm 0.5 \mu \mathrm{mol} \mathrm{CO} \mathrm{Cm}^{-2}$ at $28.9{ }^{\circ} \mathrm{C}$ in July 2010 ; mean \pm SE). 
Table 1 Nonlinear regression estimates (Lloyd and Taylor 1994) of annual $\mathrm{CO}_{2}$ efflux rates at $10{ }^{\circ} \mathrm{C}\left(R_{10}\right)$, temperature sensitivity $\left(Q_{10}\right)$ with bootstraped $95 \%$ confidence intervals

\begin{tabular}{|c|c|c|c|c|c|c|c|c|c|}
\hline $\begin{array}{l}\mathrm{CO}_{2} \\
\text { efflux }\end{array}$ & Period & $\begin{array}{l}\text { Treatment } \\
\left(\mathrm{CO}_{2}\right)\end{array}$ & $R_{10}$ & $\begin{array}{l}95 \% \mathrm{CI} \\
\text { of } R_{10}\end{array}$ & $Q_{10}$ & $\begin{array}{l}95 \% \mathrm{CI} \\
\text { of } Q_{10}\end{array}$ & $\begin{array}{l}\text { Explained } \\
\text { variation }(\%)\end{array}$ & $\begin{array}{l}\text { Annual } \mathrm{C} \text { release } \\
\left(\mathrm{g} \mathrm{m}^{-2} \mathrm{a}^{-1}\right)^{\mathrm{a}}\end{array}$ & $\begin{array}{l}\text { Change } \\
(\%)^{\mathrm{c}}\end{array}$ \\
\hline \multirow[t]{8}{*}{ Stem } & PF $2009^{b}$ & $\mathrm{C}$ & 1.6 & $0.8-3.1$ & 2.0 & $1.2-3.7$ & 35 & 596 & n.a. \\
\hline & PF $2009^{b}$ & $\mathrm{E}$ & n.a. & n.a. & n.a. & n.a. & n.a. & n.a. & \\
\hline & F 2009 & $\mathrm{C}$ & 0.7 & $0.6-0.9$ & 2.7 & $1.8-4.3$ & 80 & 318 & 4 \\
\hline & F 2009 & $\mathrm{E}$ & 0.8 & $0.5-0.9$ & 2.7 & $1.7-6.8$ & 63 & 329 & \\
\hline & F 2010 & $\mathrm{C}$ & 1.3 & $1.1-1.7$ & 1.9 & $1.6-2.3$ & 68 & 450 & -7 \\
\hline & F 2010 & $\mathrm{E}$ & 1.3 & $1.0-1.6$ & 1.9 & $1.5-2.3$ & 60 & 418 & \\
\hline & F 2011 & $\mathrm{C}$ & 0.9 & $0.1-1.6$ & 2.5 & $1.5-30.0$ & 74 & 460 & -14 \\
\hline & F 2011 & $\mathrm{E}$ & 0.9 & $0.2-1.2$ & 2.4 & $1.7-10.1$ & 81 & 396 & \\
\hline \multirow[t]{10}{*}{ Soil } & PF $2008^{b}$ & $\mathrm{C}$ & 2.5 & $2.2-2.8$ & 2.0 & $1.6-2.6$ & 58 & 887 & 19 \\
\hline & PF $2008^{b}$ & $\mathrm{E}$ & 2.9 & $2.6-3.3$ & 1.7 & $1.2-2.2$ & 38 & 1059 & \\
\hline & PF $2009^{b}$ & $\mathrm{C}$ & 2.4 & $2.2-2.7$ & 2.2 & $1.7-2.8$ & 52 & 906 & 23 \\
\hline & PF $2009^{b}$ & $\mathrm{E}$ & 3.0 & $2.9-3.3$ & 2.0 & $1.7-2.4$ & 62 & 1117 & \\
\hline & F 2009 & $\mathrm{C}$ & 2.4 & $2.2-2.6$ & 2.0 & $1.7-2.4$ & 66 & 909 & 4 \\
\hline & F 2009 & $\mathrm{E}$ & 2.3 & $2.1-2.5$ & 2.4 & $2.0-2.9$ & 73 & 948 & \\
\hline & F 2010 & $\mathrm{C}$ & 2.2 & $2.0-2.4$ & 2.5 & $2.2-3.0$ & 84 & 784 & -8 \\
\hline & F 2010 & $\mathrm{E}$ & 2 & $1.8-2.1$ & 3.3 & $2.8-3.8$ & 88 & 723 & \\
\hline & F 2011 & $\mathrm{C}$ & 2.1 & $1.9-2.3$ & 2.5 & $2.1-3.0$ & 80 & 845 & -11 \\
\hline & F 2011 & $\mathrm{E}$ & 1.8 & $1.6-2.0$ & 2.8 & $2.3-3.5$ & 77 & 750 & \\
\hline
\end{tabular}

FACE Free air $\mathrm{CO}_{2}$ enrichment, $P F$ pre-FACE, $F$ FACE, $C$ control trees, $E \mathrm{CO}_{2}$-treated trees

${ }^{\text {a }}$ based on temperature records in the litter layer (soil $\mathrm{CO}_{2}$ efflux), or $2 \mathrm{~m}$ above ground (stem $\mathrm{CO}_{2}$ efflux)

b Pre-FACE: uncorrected values

c Percentage increase in the annual carbon release from trees subjected to elevated $\mathrm{CO}_{2}$ versus control trees

\section{Discussion}

This project aimed at identifying respiratory and root growth responses in tall $P$. abies trees to elevated atmospheric $\mathrm{CO}_{2}$ concentration. Stable carbon isotope signals allowed us to trace the fate of new carbon from the tree tops to the soil, and these data confirmed the effectiveness of our $\mathrm{CO}_{2}$ treatment (Mildner et al. 2014). We expected that these 110-year-old spruce trees have reached a steady-state annual canopy and fine root renewal. A sudden exposure to a $150 \mathrm{ppm}$ higher $\mathrm{CO}_{2}$ concentration may thus cause strong initial, but declining long-term responses (Leuzinger et al. 2011; Norby and Zak 2011). In fact, we did not observe any significant downward adjustment of leaf-level photosynthesis at $\mathrm{eCO}_{2}$ in current and previous year needles shortly after the onset of FACE in 2009 (n.s.; Fig. S5). In the fifth year of FACE, rates of photosynthesis remained enhanced at $\mathrm{eCO}_{2}$, and the photosynthetic enhancement
(CI), and annual cumulative $\mathrm{C}$ fluxes from stems and soil of Picea abies under elevated or ambient $\mathrm{CO}_{2}$ 
Table 2 Linear mixed effects model results for Picea abies fine root biomass (soil cores integrating until 2010; and in-growth cores March 2010 to December 2011), and $\mathrm{CO}_{2}$ efflux from stems and soil under ambient and elevated $\mathrm{CO}_{2}$
* $P<0.05$; ** $P<0.01$; *** $P<0.001$

\begin{tabular}{|c|c|c|c|}
\hline Factor & Df & $F$ value & $P$ \\
\hline \multicolumn{4}{|l|}{ Fine root biomass in soil cores (2010) } \\
\hline Diameter & 2,16 & 86.59 & $<0.001 * * *$ \\
\hline Site & 1,8 & 1.85 & 0.211 \\
\hline Diameter $\times$ site & 2,16 & 14.27 & $0.001 * *$ \\
\hline \multicolumn{4}{|l|}{ Fine root biomass in in-growth cores (2010-2011) } \\
\hline Diameter & 2,16 & 31.13 & $<0.001 * * *$ \\
\hline $\mathrm{CO}_{2}$ & 1,8 & 0.34 & 0.575 \\
\hline Diameter $\times \mathrm{CO}_{2}$ & 2,16 & 4.14 & $0.036^{*}$ \\
\hline \multicolumn{4}{|l|}{ Stem $\mathrm{CO}_{2}$ efflux 2009-2011 } \\
\hline Bark temperature & 1,106 & 24.99 & $<0.001 * * *$ \\
\hline Pre-treatment & 1,106 & 12.70 & $0.001 * *$ \\
\hline \multicolumn{4}{|l|}{ Soil $\mathrm{CO}_{2}$ efflux 2008-2011 } \\
\hline $\mathrm{CO}_{2}$ & 1,8 & 7.55 & 0.025 \\
\hline Pre-treatment & 1,308 & 251.06 & $<0.001 * * *$ \\
\hline Soil temperature & 1,308 & 1655.21 & $<0.001 * * *$ \\
\hline Soil moisture & 1,308 & 1.29 & 0.257 \\
\hline $\mathrm{CO}_{2} \times$ pre-treatment & 1,308 & 13.44 & $<0.001 * * *$ \\
\hline $\mathrm{CO}_{2} \times$ soil temperature & 1,308 & 2.51 & 0.114 \\
\hline Pre-treatment $\times$ soil temperature & 1,308 & 0.78 & 0.378 \\
\hline $\mathrm{CO}_{2} \times$ soil moisture & 1,308 & 1.14 & 0.287 \\
\hline Pre-treatment $\times$ soil moisture & 1,308 & 0.12 & 0.733 \\
\hline Soil temperature $\times$ soil moisture & 1,308 & 4.44 & $0.036^{*}$ \\
\hline Soil moisture $\times$ soil temperature $\times$ pre-treatment & 1,308 & 9.80 & $0.002 * *$ \\
\hline
\end{tabular}

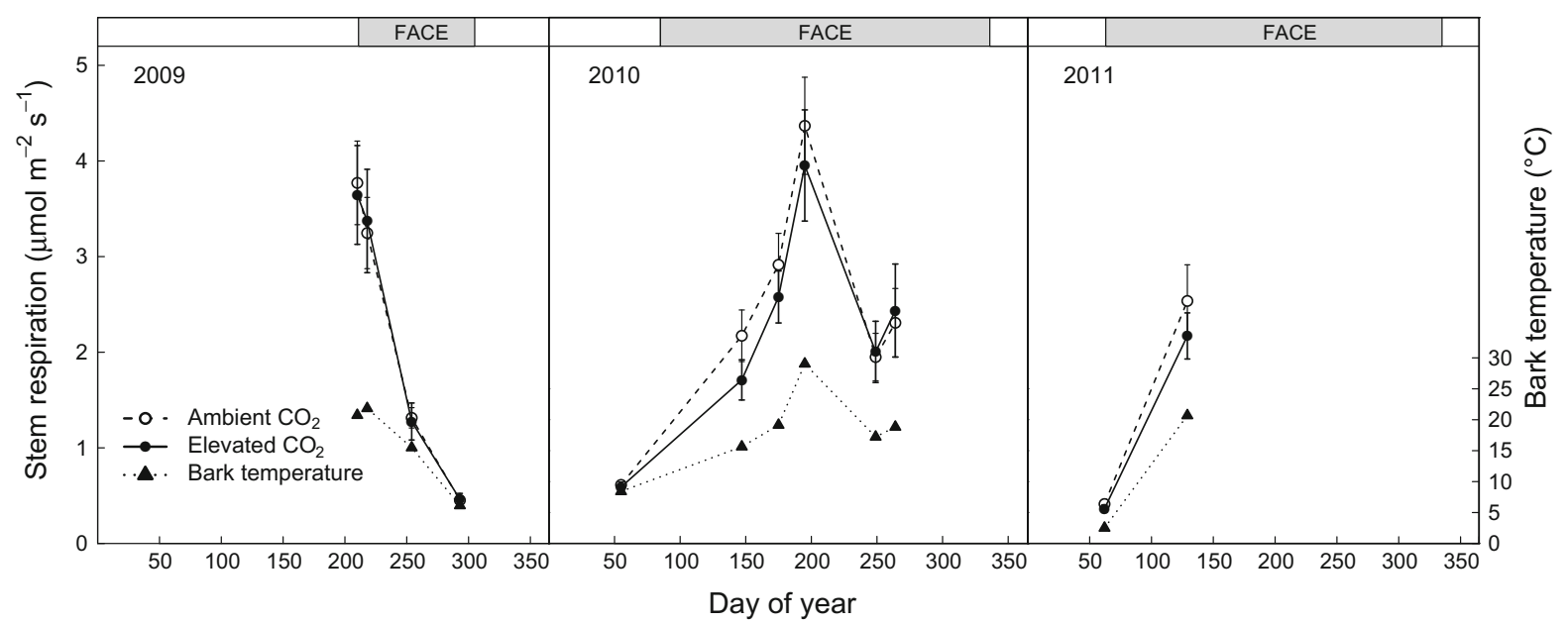

Fig. 4 Stem respiration $\left(R_{\text {stem }}\right)$ and bark surface temperature of mature Picea abies exposed to ambient, or elevated atmospheric $\mathrm{CO}_{2}$ concentrations in 2009, 2010, and 2011 (ambient $\mathrm{CO}_{2}$ : $n=5$ trees; elevated $\mathrm{CO}_{2}: n=5$ trees; mean $\pm \mathrm{SE}$ ). $R_{\text {stem }}$ of trees exposed to elevated $\mathrm{CO}_{2}$ was corrected for the pre- treatment difference observed between control and treated trees (see materials and methods). Bark surface temperature under elevated and ambient $\mathrm{CO}_{2}$ did not differ (n.s.). Therefore, the mean of all trees is plotted $(n=10)$. The grey-shaded areas on top of the panels denote the FACE periods 


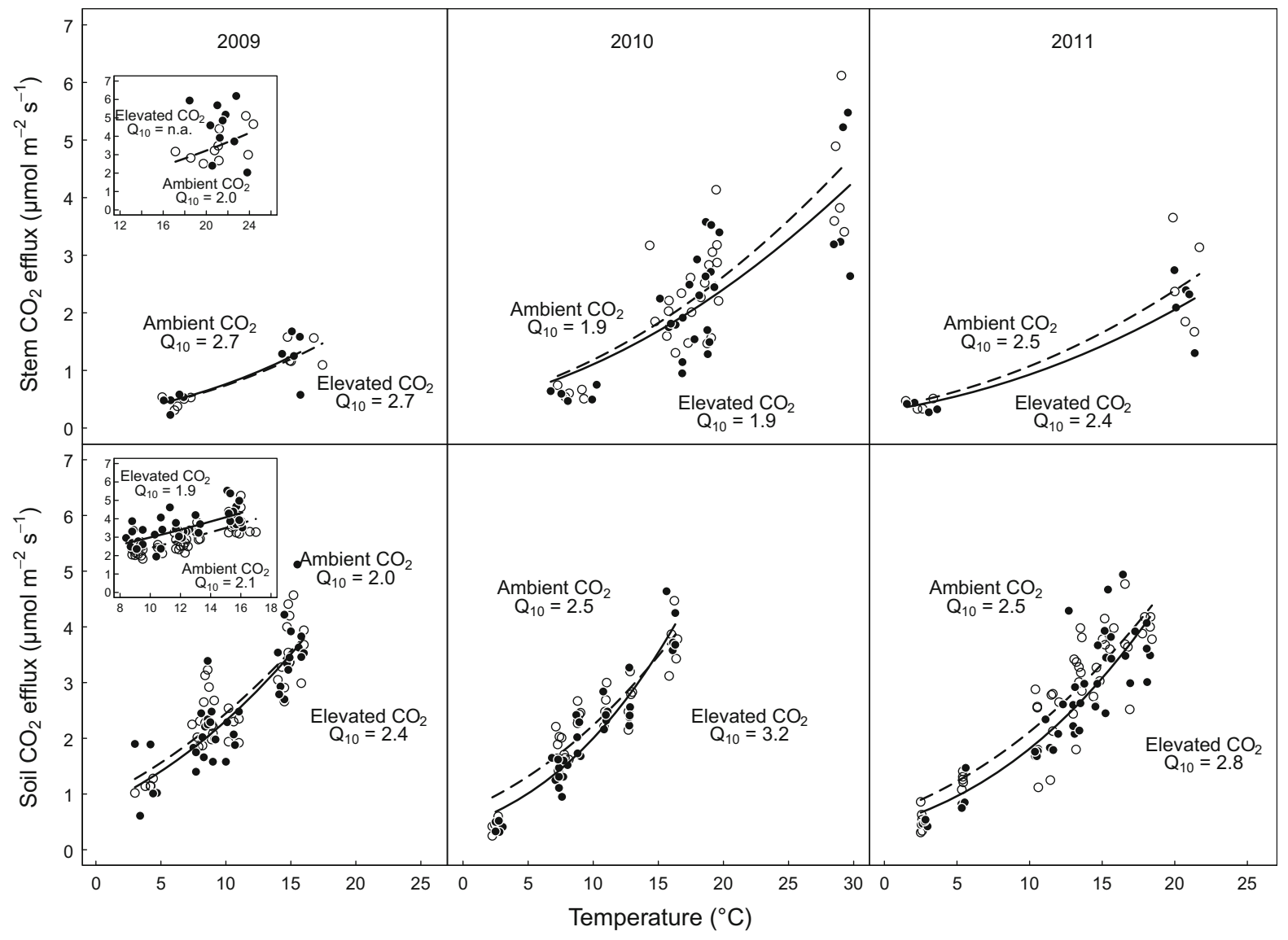

Fig. 5 Picea abies stem respiration $\left(R_{\text {stem }}\right)$ response to bark surface temperature (upper panels), and soil respiration $\left(R_{\text {soil }}\right)$ response to soil temperature $10 \mathrm{~cm}$ below ground (lower panels) during the FACE periods of the years 2009, 2010, and 2011. $R_{\text {stem }}$ and $R_{\text {soil }}$ of trees exposed to elevated $\mathrm{CO}_{2}$ were corrected for the pre-treatment difference observed between control and treated trees (see materials and methods). The inset diagrams in 2009 depict the pre-treatment uncorrected $R_{\text {stem }}$ (upper inset) and $R_{\text {soil }}$ (lower inset) response in the period before the initiation

when compared to the pre-treatment signals. These results contrast observations in juvenile trees where increased fine root production at $\mathrm{eCO}_{2}$ was found in $P$. abies grown in open top chambers (Lebègue et al. 2004), or in Glass Domes (Pokorný et al. 2013), regenerating birch/aspen stands, three Populus species, and young deciduous trees of three species, all grown under FACE (Lukac et al. 2003; Pregitzer et al. 2008; Smith et al. 2013). In the Oak Ridge FACE experiment, a plantation of Liquidambar styraciflua (21-year-old in 2009) showed an increase in fine root production and mortality during the first 7 years (Norby et al. 2004), but the signal disappeared after of FACE in 2009. All respiration measurements were fitted with Lloyd and Taylor (1994) functions. Trees were exposed to ambient (open symbols, dashed line), or elevated atmospheric $\mathrm{CO}_{2}$ concentrations (filled symbols, solid line). Each symbol represents the mean $R_{\text {stem }}$ or $R_{\text {soil }}$ rates measured per tree ( $n=2-4)$ and measurement campaign. The $Q_{10}$ values indicate the mean increase in the $R_{\text {stem }}$ or $R_{\text {soil }}$ rate per $10{ }^{\circ} \mathrm{C}$ temperature increase (from 5 to $15^{\circ} \mathrm{C}$ )

11 years due to progressive $\mathrm{N}$-limitation (Norby et al. 2010). An initial stimulation of fine root production by $\mathrm{eCO}_{2}$ was also reported for a young closed-canopy Pinus taeda plantation at the Duke FACE (Allen et al. 2000). These studies investigated young trees, which may not have completely explored the available soil volume, and mostly grew under ample nutrient supply (expanding systems; Körner 2006).

The soil space beneath mature trees in a fully-grown forest can be expected to be fully explored by roots and to have arrived at a steady-state fine root turnover, which would prevent stimulation by $\mathrm{eCO}_{2}$ (Norby et al. 1999; Körner 2006). The 110-year-old trees studied in our 
web-FACE experiment operated at constant annual needle renewal rates (unpublished litter production data) and, thus, should also be in a steady-state of fine root renewal, not affected by e $\mathrm{CO}_{2}$ (Körner 2006; Norby and Zak 2011). A Swiss treeline FACE study on 35-year-old L. decidua and Pinus uncinata, both in a quasi steady-state development, did not reveal any fine root growth following high $\mathrm{CO}_{2}$ exposure despite higher soil $\mathrm{CO}_{2}$ efflux (Handa et al. 2008; Dawes et al. 2013; Hagedorn et al. 2013). Additionally, a $\mathrm{CO}_{2}$ enrichment experiment in a scrub-oak system in Florida showed an initial burst of fine root production under $\mathrm{eCO}_{2}$ after disturbances (fire and hurricane), a signal that gradually vanished in the following years (Day et al. 2013) with canopy closure (full LAI recovery; Palmroth et al. 2006). The former web-FACE study at our site on mature deciduous forest trees showed even reduced fine root production after 7 years of $\mathrm{eCO}_{2}$ (Bader et al. 2009). This was explained by stand maturation, and (stomata driven) reduced canopy transpiration. Thus, soil moisture savings reduced the need for intensified soil exploration by fine roots (Leuzinger and Körner 2007; Bader et al. 2009). In contrast, our spruce trees showed no reduction of sap flow when exposed to $\mathrm{eCO}_{2}$ and, hence, exhibited no soil moisture savings that might be responsible for the missing fine root growth response (Leuzinger and Bader 2012).

Abundance of soil nutrients, especially the availability of $\mathrm{N}$, determines how fine roots will respond to $\mathrm{eCO}_{2}$ (Pregitzer et al. 1995; Curtis and Wang 1998; De Graaff et al. 2006; Dieleman et al. 2010), regardless of tree or stand age. Recently two meta-analyses investigated the interactive effects of high $\mathrm{CO}_{2}$ and $\mathrm{N}$ availability in soils, with high soil $\mathrm{N}$ fueling the $\mathrm{CO}_{2}$ effect on fine root growth (De Graaff et al. 2006; Dieleman et al. 2010). This contradicts our results since we found no fine root response to $\mathrm{eCO}_{2}$ despite decades of $\mathrm{N}$-deposition of ca. $20 \mathrm{~kg} \mathrm{~N} \mathrm{ha}^{-1} \mathrm{a}^{-1}$ at our site. Additionally, $\mathrm{CO}_{2}$ enrichment induced soil nitrate release both in the present study (unpublished data), and in the former web-FACE experiment on mature deciduous trees (Schleppi et al. 2012). In Pinus taeda at the Duke FACE site, $\mathrm{N}$-fertilization reduced fine root biomass by ca. $12 \%$ compared to unfertilized plots, accompanied by reductions in soil respiration (Jackson et al. 2009; Drake et al. 2011). In 6-8-yearold $P$. abies saplings, $\mathrm{N}$-addition reduced fine root production in comparison to plots without extra $\mathrm{N}$ in $\mathrm{CO}_{2}$-enriched plots (Spinnler et al. 2002). It appears that the trees in this near-natural, mature forest do not exhibit such $\mathrm{N}$-mediated fine root responses to $\mathrm{eCO}_{2}$.

Given the substantial atmospheric $\mathrm{N}$ deposition in the test region, PNL, caused by accelerated soil $\mathrm{N}$ withdrawal during long-term $\mathrm{CO}_{2}$ enrichment (Luo et al. 2004), is unlikely to occur here and stimulate fine root expansion under high $\mathrm{CO}_{2}$ (see Franklin et al. 2009; Garten et al. 2011 for PNL effects).

$\mathrm{CO}_{2}$ fertilization may also induce deeper rooting, a phenomenon commonly observed in $\mathrm{CO}_{2}$ enrichment experiments (Lukac et al. 2003; Norby et al. 2004; Jackson et al. 2009; Iversen 2010; Smith et al. 2013). However, we could not explore this possibility here, because the accessible soil profile at the SCC site is maximal $25 \mathrm{~cm}$ deep, with extremely rocky subsoil.

\section{Soil respiration}

In the short term, $R_{\text {soil }}$ is mainly controlled by soil moisture and soil temperature (Raich and Schlesinger 1992; Davidson et al. 1998). When accounting for these covariates plus pre-treatment signals (Fig. S1), we detected a trend towards reduced $R_{\text {soil }}$ in response to FACE. Spruce trees under $\mathrm{eCO}_{2}$ also showed continuously decreasing annual $\mathrm{C}$ returns to the atmosphere compared to control trees (Table 1). The (moderate) reduction of $\mathrm{CO}_{2}$ release compared to pretreatment conditions is surprising, given that soil $\mathrm{CO}_{2}$ efflux carried a clear ${ }^{13} \mathrm{C}$ signal that indicates effective $\mathrm{CO}_{2}$ enrichment and fast belowground allocation of new C (Mildner et al. 2014). The absolute reduction in $R_{\text {soil }}$ in response to $\mathrm{eCO}_{2}$ might be even more pronounced, had the soil space been fully occupied by $P$. abies fine roots instead of a ca. $50 \%$ fraction of all fine roots, including those from neighboring deciduous trees. The finding of reduced $R_{\text {soil }}$ contrasts with many examples for very young stands (mostly obtained in open top chambers, OTC) that showed increased but highly variable $R_{\text {soil }}$ under $\mathrm{eCO}_{2}$ (plus 5-93\%) compared to $\mathrm{aCO}_{2}$ (Zak et al. 2000). Forest FACE experiments in young plantations initially showed increases in $R_{\text {soil }}$ rates at $\mathrm{eCO}_{2}$, but these signals declined with time (Hamilton et al. 2002; King et al. 2004; Comstedt et al. 2006; Jackson et al. 2009; Norby and Zak 2011). Dieleman et al. (2010) summarized the results for 32 OTC and FACE sites using trees and found an average $19 \%$ increase in $R_{\text {soil }}$, with soil $\mathrm{N}$ fertilization enhancing the $\mathrm{CO}_{2}$ effect. However, a few $\mathrm{CO}_{2}$ enrichment experiments 
showed no stimulation or a decline of $R_{\text {soil }}$, e.g. soil under mature deciduous trees subjected to web-FACE at our study site ( $\mathrm{N}$-fertilized soil) did not release more $\mathrm{CO}_{2}$ under $\mathrm{eCO}_{2}$. This was attributed to higher soil moisture at $\mathrm{eCO}_{2}$ that may have impeded soil $\mathrm{CO}_{2}$ efflux (Bader and Körner 2010). Furthermore, Tingey et al. (2006) reported declining rates of $R_{\text {soil }}$ in Ponderosa pine seedlings subjected to $\mathrm{eCO}_{2}$ in growth chambers, caused by altered $R_{\text {soil }}$ sensitivity to soil temperature and soil moisture at $\mathrm{eCO}_{2}$.

The extent to which $R_{\text {soil }}$ responds to $\mathrm{eCO}_{2}$ has been found to be strongly related to responses of fine roots (Zak et al. 2000; Jackson et al. 2009; Drake et al. 2011). Root respiration (and associated mycorrhizal fungal respiration) can contribute 50-65\% to total $R_{\text {soil }}$ (Andrews et al. 1999; Högberg et al. 2001, 2002; Bhupinderpal-Singh et al. 2003), and is fueled by fresh aboveground assimilates (Högberg et al. 2001). Therefore, the relative reduction in $R_{\text {soil }}$ is likely to reflect reduced belowground $\mathrm{C}$ transfer under $\mathrm{eCO}_{2}$ (Palmroth et al. 2006; but see Jastrow et al. 2005). Generally, C supply to belowground microorganisms, or fungal symbionts was found to either increase with $\mathrm{CO}_{2}$ fertilization, or did not change (Fransson 2012). In the short term, extra $\mathrm{C}$ is likely to increase the abundance of microorganisms (e.g. fungi and bacteria; Blankinship et al. 2011) which may become competitors for essential plant nutrients (Diaz et al. 1993; Hättenschwiler and Körner 1998; Inauen et al. 2012). Likewise, heterotrophic rhizomicrobial respiration could decline when exudates alter the microbial community (Bader and Körner 2010), its activity (Drake et al. 2011), or species composition (Carney et al. 2007; Drigo et al. 2008; reviewed in Zak et al. 2000). A higher release of nitrate under $\mathrm{eCO}_{2}$ relative to $\mathrm{aCO}_{2}$ (Schleppi and Textor, pers. comm.; similar to Schleppi et al. 2012) could also contribute to reduced microbial activity. However, we expected the 'priming effect' (Jenkinson et al. 1985) to dominate, as was found in the Duke FACE study (Drake et al. 2011; Phillips et al. 2012) that reported slowly increasing $R_{\text {soil }}$ over the course of 12 years of FACE (Jackson et al. 2009). The tall, 110-year-old trees in our study may either respond more slowly, or have their roots spread over such a large area that $R_{\text {soil }}$ signals get diluted.

\section{Stem respiration}

During the first 2.5 years of web-FACE, there was no indication of a $\mathrm{CO}_{2}$-driven decline or increase of $R_{\text {stem }}$ in these mature $P$. abies trees, although a strong stable $\mathrm{C}$ isotope signal in respiratory $\mathrm{CO}_{2}$ evidences that the novel $\mathrm{C}$ derived from web-FACE (Mildner et al. 2014). The lack of any stem growth stimulation at $\mathrm{eCO}_{2}$ in these trees (the 2009-2014 mean basal area increment standardized by mean pre-treatment rates was $1.4 \pm 0.1$ at $\mathrm{aCO}_{2}$ and $1.5 \pm 0.3$ at $\mathrm{eCO}_{2}$; $n=6$ years, mean \pm SE; Klein and Körner; unpublished), given the assumption that the stem diameter increment largely determines the magnitude of $R_{\text {stem }}$ signals under $\mathrm{eCO}_{2}$ (Zha et al. 2005; Moore et al. 2008), co-explains why we also see no $R_{\text {stem }}$ signal in response to web-FACE. In contrast to these results, juvenile trees exposed to a step increase in $\mathrm{CO}_{2}$ on fertile ground, or with ample soil space, grew faster and their stems respired more. For instance, $R_{\text {stem }}$ was $16 \%$ higher in $\mathrm{eCO}_{2}$ in 16-year-old $P$. abies (Acosta et al. 2010). Similarly, an increase in $R_{\text {stem }}$ in response to $\mathrm{eCO}_{2}$ was observed in 15-year-old Liquidambar styraciflua (Edwards et al. 2002), and in 20-year-old $P$. sylvestris (Zha et al. 2005). Stem growth and the associated $R_{\text {stem }}$ responses to $\mathrm{eCO}_{2}$ are largely determined by the developmental stage (age) of a tree, the species investigated, and the nutrient supply (Körner 2006). $\mathrm{CO}_{2}$ enrichment may also contribute to higher maintenance respiration (Carey et al. 1996; Edwards et al. 2002; Zha et al. 2005), and mature trees exhibit higher maintenance respiration rates than juvenile trees (Ryan and Waring 1992). Hence, mature trees might be expected to yield even greater responses, but this is in contrast to what we found. $R_{\text {stem }}$ signals might become diminished by translocation of dissolved $\mathrm{CO}_{2}$ in sap flow (Negisi 1979; Teskey and McGuire 2002; Moore et al. 2008; Bloemen et al. 2013). However, sap flow measured prior to web-FACE was similar in the trees examined, and this relation did not change at $\mathrm{eCO}_{2}$ (Leuzinger and Bader 2012). Whatever the reason, these tall trees did not exhibit a greater $R_{\text {stem }}$ response under web-FACE.

\section{Conclusions and outlook}

Previous and ongoing works revealed that photosynthesis, was, and still is, enhanced under $\mathrm{eCO}_{2}$, and stomatal conductance remained unaffected by $\mathrm{eCO}_{2}$ (Leuzinger and Bader 2012). Therefore, we expected strong and positive initial responses to a step increase in $\mathrm{CO}_{2}$ in both types of respiratory $\mathrm{CO}_{2}$ release, and in fine root growth in these tall trees. The fact that we did 
not detect such a stimulation, despite clear isotopic evidence of successful canopy $\mathrm{CO}_{2}$ enrichment, by default, suggests other pathways of C-dissipation under $\mathrm{eCO}_{2}$. We expected such overflow responses because we (seemingly correctly) anticipated no stem growth response for reasons related to tree nutrition (other than by $\mathrm{N}$ ), and tissue element stoichiometry (ongoing research). It remains to be seen if accelerated root growth will occur at a later stage, as was the case in other FACE works (Allen et al. 2000; Spinnler et al. 2002; Norby et al. 2004). The fine root data should be highly sensitive to $\mathrm{CO}_{2}$ because fine roots from ingrowth cores had not yet arrived at steady-state root density, and the signal should still capture the root expansion process. The data presented here add to the growing evidence that mature trees or trees growing in stands that arrived at steady-state leaf and root turnover are unlikely to take benefit from $\mathrm{eCO}_{2}$. These trees are likely to be $\mathrm{C}$ saturated at current ambient $\mathrm{CO}_{2}$ concentrations, as has been shown for boreal spruce trees (Sigurdsson et al. 2013). We observed highly homeostatic stem respiratory signals, and soil $\mathrm{CO}_{2}$ efflux even declined slightly in response to web-FACE.

Acknowledgments We are particularly indebted to E. Amstutz and $\mathrm{G}$. Grun who kept the free air $\mathrm{CO}_{2}$ enrichment system running. We are also notably obliged to $S$. Jakob, and several student helpers for their support in data collection and sample processing. We thank T. Klein for providing additional fine root biomass and preliminary stem basal increment data that supported our argumentation. Thanks to T. Baisden and the invaluable comments from three anonymous reviewers that greatly helped in improving earlier drafts. Funding came from the Swiss National Science Foundation (Grant Nos 31003AB-126028 and 31003A_140753, $31-67775.02$, 3100-059769.99, 3100-067775.02, and 3100AO111914/1). The crane was sponsored by the Swiss Federal Office of the Environment (FOEN).

\section{References}

Acosta M, Pokorný R, Janouš D, Marek MV (2010) Stem respiration of Norway spruce trees under elevated $\mathrm{CO}_{2}$ concentration. Biol Plant 54:773-776

Allen AS, Andrews JA, Finzi AC, Matamala R, Richter DD, Schlesinger WH (2000) Effects of free-air $\mathrm{CO}_{2}$ enrichment (FACE) on belowground processes in a Pinus taeda forest. Ecol Appl 10:437-448

Andrews JA, Harrison KG, Matamala R, Schlesinger WH (1999) Separation of root respiration from total soil respiration using carbon-13 labeling during free-air carbon dioxide enrichment (FACE). Soil Sci Soc Am J 63:1429-1435
Bader MKF, Körner C (2010) No overall stimulation of soil respiration under mature deciduous forest trees after 7 years of $\mathrm{CO}_{2}$ enrichment. Glob Change Biol 16:2830-2843

Bader MKF, Hiltbrunner E, Körner C (2009) Fine root responses of mature deciduous forest trees to free air carbon dioxide enrichment (FACE). Funct Ecol 23:913-921

Bader MKF, Siegwolf RTW, Körner C (2010) Sustained enhancement of photosynthesis in mature deciduous forest trees after 8 years of free air $\mathrm{CO}_{2}$ enrichment. Planta 232:1115-1125

Bader MKF, Leuzinger S, Keel SG, Siegwolf RTW, Hagedorn F, Schleppi P, Körner C (2013) Central European hardwood trees in a high- $\mathrm{CO}_{2}$ future: synthesis of an 8-year forest canopy $\mathrm{CO}_{2}$ enrichment project. J Ecol 101:1509-1519

Bernhardt ES, Barber JJ, Pippen JS, Taneva L, Andrews JA, Schlesinger WH (2006) Long-term effects of free air $\mathrm{CO}_{2}$ enrichment (FACE) on soil respiration. Biogeochemistry 77:91-116

Bhupinderpal-Singh NA, Ottosson-Löfvenius M, Högberg MN, Mellander P-E, Högberg P (2003) Tree root and soil heterotrophic respiration as revealed by girdling of boreal Scots pine forest: extending observations beyond the first year. Plant Cell Environ 26:1287-1296

Blankinship JC, Niklaus PA, Hungate BA (2011) A meta-analysis of responses of soil biota to global change. Oecologia 165:553-565

Bloemen J, McGuire MA, Aubrey DP, Teskey RO, Steppe K (2013) Transport of root-respired $\mathrm{CO}_{2}$ via the transpiration stream affects aboveground carbon assimilation and $\mathrm{CO}_{2}$ efflux in trees. New Phytol 197:555-565

Carey EV, DeLucia EH, Ball JT (1996) Stem maintenance and construction respiration in pinus ponderosa grown in different concentrations of atmospheric $\mathrm{CO}_{2}$. Tree Physiol 16:125-130

Carney KM, Hungate BA, Drake BG, Megonigal JP (2007) Altered soil microbial community at elevated $\mathrm{CO}_{2}$ leads to loss of soil carbon. P Natl Acad Sci USA 104:4990-4995

Comstedt D, Boström B, Marshall JD, Holm A, Slaney M, Linder S, Ekblad A (2006) Effects of elevated atmospheric carbon dioxide and temperature on soil respiration in a boreal forest using $\delta^{13} \mathrm{C}$ as a labeling tool. Ecosystems 9:1266-1277

Curtis PS, Wang XZ (1998) A meta-analysis of elevated $\mathrm{CO}_{2}$ effects on woody plant mass, form, and physiology. Oecologia 113:299-313

Darbah JNT, Kubiske ME, Nelson N, Kets K, Riikonen J, Sober A, Rouse L, Karnosky DF (2010) Will photosynthetic capacity of aspen trees acclimate after long-term exposure to elevated $\mathrm{CO}_{2}$ and $\mathrm{O}_{3}$ ? Environ Pollut 158:983-991

Davidson EA, Belk E, Boone RD (1998) Soil water content and temperature as independent or confounded factors controlling soil respiration in a temperate mixed hardwood forest. Glob Change Biol 4:217-227

Dawes MA, Hagedorn F, Handa IT, Streit K, Ekblad A, Rixen C, Körner C, Hättenschwiler S (2013) An alpine treeline in a carbon dioxide-rich world: synthesis of a nine-year free-air carbon dioxide enrichment study. Oecologia 171:623-637

Day FP, Schroeder RE, Stover DB, Brown ALP, Butnor JR, Dilustro J, Hungate BA, Dijkstra P, Duval BD, Seiler TJ, Drake BG, Hinkle CR (2013) The effects of $11 \mathrm{yr}$ of $\mathrm{CO}_{2}$ enrichment on roots in a Florida scrub-oak ecosystem. New Phytol 200:778-787 
De Graaff MA, Van Groenigen KJ, Six J, Hungate B, Van Kessel C (2006) Interactions between plant growth and soil nutrient cycling under elevated $\mathrm{CO}_{2}$ : a meta-analysis. Glob Change Biol 12:2077-2091

Diaz S, Grime JP, Harris J, McPherson E (1993) Evidence of a feedback mechanism limiting plant response to elevated carbon dioxide. Nature 364:616-617

Dieleman WI, Luyssaert S, Rey A, de Angelis P, Barton CV, Broadmeadow MS, Broadmeadow SB, Chigwerewe KS, Crookshanks M, Dufrêne E, Jarvis PG, Kasurinen A, Kellomäki S, Le Dantec V, Liberloo M, Marek M, Medlyn B, Pokorný R, Scarascia-Mugnozza G, Temperton VM, Tingey D, Urban O, Ceulemans R, Janssens IA (2010) Soil [N] modulates soil $\mathrm{C}$ cycling in $\mathrm{CO}_{2}$-fumigated tree stands: a meta-analysis. Plant Cell Environ 33:2001-2011

Drake JE, Gallet-Budynek A, Hofmockel KS, Bernhardt ES, Billings SA, Jackson RB, Johnsen KS, Lichter J, McCarthy HR, McCormack ML, Moore DJP, Oren R, Palmroth S, Phillips RP, Pippen JS, Pritchard SG, Treseder KK, Schlesinger WH, DeLucia EH, Finzi AC (2011) Increases in the flux of carbon belowground stimulate nitrogen uptake and sustain the long-term enhancement of forest productivity under elevated $\mathrm{CO}_{2}$. Ecol Lett 14:349-357

Drigo B, Kowalchuk GA, van Veen JA (2008) Climate change goes underground: effects of elevated atmospheric $\mathrm{CO}_{2}$ on microbial community structure and activities in the rhizosphere. Biol Fert Soils 44:667-679

Edwards NT, Tschaplinski TJ, Norby RJ (2002) Stem respiration increases in $\mathrm{CO}_{2}$-enriched sweetgum trees. New Phytol 155:239-248

Ellsworth DS, Thomas R, Crous KY, Palmroth S, Ward E, Maier C, DeLucia EH, Oren R (2012) Elevated CO2 affects photosynthetic responses in canopy pine and subcanopy deciduous trees over 10 years: a synthesis from Duke FACE. Glob Change Biol 18:223-242

Fierer N, Strickland MS, Liptzin D, Bradford MA, Cleveland CC (2009) Global patterns in belowground communities. Ecol Lett 12:1238-1249

Franklin O, McMurtrie RE, Iversen CM, Crous KY, Finzi AC, Tissue DT, Ellsworth DS, Oren R, Norby RJ (2009) Forest fine-root production and nitrogen use under elevated $\mathrm{CO}_{2}$ : contrasting responses in evergreen and deciduous trees explained by a common principle. Glob Change Biol 15:132-144

Fransson P (2012) Elevated $\mathrm{CO}_{2}$ impacts ectomycorrhiza-mediated forest soil carbon flow: fungal biomass production, respiration and exudation. Fungal Ecol 5:85-98

Garten CT, Iversen CM, Norby RJ (2011) Litterfall $N^{15}$ abundance indicates declining soil Nitrogen availability in a free-air $\mathrm{CO}_{2}$ enrichment experiment. Ecology 92:133-139

Hagedorn F, Hiltbrunner D, Streit K, Ekblad A, Lindahl BD, Miltner A, Frey B, Handa IT, Hättenschwiler S (2013) Nine years of $\mathrm{CO}_{2}$ enrichment at the alpine treeline stimulates soil respiration but does not alter soil microbial communities. Biogeochemistry 57:390-400

Hamilton JG, DeLucia EH, George K, Naidu SL, Finzi AC, Schlesinger WH (2002) Forest carbon balance under elevated $\mathrm{CO}_{2}$. Oecologia 131:250-260

Handa IT, Hagedorn F, Hättenschwiler S (2008) No stimulation in root production in response to 4 years of in situ $\mathrm{CO}_{2}$ enrichment at the Swiss treeline. Funct Ecol 22:348-358
Hättenschwiler S, Körner C (1998) Biomass allocation and canopy development in spruce model ecosystems under elevated $\mathrm{CO}_{2}$ and increased $\mathrm{N}$ deposition. Oecologia 113:104-114

Hättenschwiler S, Miglietta F, Raschi A, Körner C (1997) Thirty years of in situ tree growth under elevated $\mathrm{CO}_{2}$ : a model for future forest responses? Glob Change Biol 3:463-471

Högberg P, Nordgren A, Buchmann N, Taylor AFS, Ekblad A, Högberg MN, Nyberg G, Ottosson-Löfvenius M, Read DJ (2001) Large-scale forest girdling shows that current photosynthesis drives soil respiration. Nature 411:789-792

Högberg P, Nordgren A, Agren GI (2002) Carbon allocation between tree root growth and root respiration in boreal pine forest. Oecologia 132:579-581

Hungate BA, Dijkstra P, Wu Z, Duval BD, Day FP, Johnson DW, Megonigal JP, Brown AL, Garland JL (2013) Cumulative response of ecosystem carbon and nitrogen stocks to chronic $\mathrm{CO}_{2}$ exposure in a subtropical oak woodland. New Phytol 200:753-766

Inauen N, Körner C, Hiltbrunner E (2012) No growth stimulation by $\mathrm{CO}_{2}$ enrichment in alpine glacier forefield plants. Glob Change Biol 18:985-999

Iversen CM (2010) Digging deeper: fine-root responses to rising atmospheric $\mathrm{CO}_{2}$ concentration in forested ecosystems. New Phytol 186:346-357

Iversen CM, Hooker TD, Classen AT, Norby RJ (2011) Net mineralization of $\mathrm{N}$ at deeper soil depths as a potential mechanism for sustained forest production under elevated $\mathrm{CO}_{2}$. Glob Change Biol 17:1130-1139

Iversen CM, Keller JK, Garten CT, Norby RJ (2012) Soil carbon and nitrogen cycling and storage throughout the soil profile in a sweetgum plantation after 11 years of $\mathrm{CO}_{2}$-enrichment. Glob Change Biol 18:1684-1697

Jackson RB, Cook CW, Pippen JS, Palmer SM (2009) Increased belowground biomass and soil $\mathrm{CO}_{2}$ fluxes after a decade of carbon dioxide enrichment in a warm-temperate forest. Ecology 90:3352-3366

Janouš D, Pokorný R, Brossaud J, Marek MV (2000) Long-term effects of elevated $\mathrm{CO}_{2}$ on woody tissues respiration of Norway spruce studied in open-top chambers. Biol Plant 43:41-46

Jastrow JD, Miller RM, Matamala R, Norby RJ, Boutton TW, Rice CW, Owensby CE (2005) Elevated atmospheric carbon dioxide increases soil carbon. Glob Change Biol 11:2057-2064

Jenkinson DS, Fox RH, Rayner JH (1985) Interactions between fertilizer nitrogen and soil nitrogen-the so-called 'priming' effect. J Soil Sci 36:425-444

King JS, Hanson PJ, Bernhardt E, De Angelis P, Norby RJ, Pregitzer KS (2004) A multiyear synthesis of soil respiration responses to elevated atmospheric $\mathrm{CO}_{2}$ from four forest FACE experiments. Glob Change Biol 10:1027-1042

Körner C (1994) Biomass fractionation in plants: a reconsideration of definitions based on plant functions. In: Roy J, Garnier E (eds) A whole plant perspective on carbon-nitrogen interactions. SPB Acad Publishing, The Hague, pp 173-185

Körner C (2000) Biosphere responses to $\mathrm{CO}_{2}$ enrichment. Ecol Appl 10:1590-1619

Körner C (2006) Plant $\mathrm{CO}_{2}$ responses: an issue of definition, time and resource supply. New Phytol 172:393-411 
Körner C, Asshoff R, Bignucolo O, Hättenschwiler S, Keel SG, Pelaez-Riedl S, Pepin S, Siegwolf RTW, Zotz G (2005) Carbon flux and growth in mature deciduous forest trees exposed to elevated $\mathrm{CO}_{2}$. Science 309:1360-1362

Lebègue C, Laitat È, Perrin D, Pissard G (2004) Mise en œuvre de carottages de sol et de minirhizotrons pour l'étude à long terme de la réponse des fines racines d'épicéa (Picea abies (1.) Karst.) à l'augmentation de la concentration en $\mathrm{CO}_{2}$ dans l'atmosphère et la nutrition minérale. Biotechnol Agron Soc 8:41-53

Leuzinger S, Körner C (2007) Water savings in mature deciduous forest trees under elevated $\mathrm{CO}_{2}$. Glob Change Biol 13:2498-2508

Leuzinger S, Bader MKF (2012) Experimental vs. modeled water use in mature norway spruce (Picea abies) exposed to elevated $\mathrm{CO}_{2}$. Front Plant Sci 3:229

Leuzinger S, Hättenschwiler S (2013) Beyond global change: lessons from 25 years of $\mathrm{CO}_{2}$ research. Oecologia 171:639651

Leuzinger S, Luo Y, Beier C, Dieleman W, Vicca S, Körner C (2011) Do global change experiments overestimate impacts on terrestrial ecosystems? Trends Ecol Evol 26:236-241

Lloyd J, Taylor JA (1994) On the temperature-dependence of soil respiration. Funct Ecol 8:315-323

Lukac M, Calfapietra C, Godbold DL (2003) Production, turnover and mycorrhizal colonization of root systems of three Populus species grown under elevated $\mathrm{CO}_{2}$ (popFACE). Glob Change Biol 9:838-848

Luo Y, Su B, Currie WS, Dukes JS, Finzi A, Hartwig U, Hungate B, McMurtrie RE, Oren R, Parton WJ, Pataki DE, Shaw MR, Zak DR, Field CB (2004) Progressive nitrogen limitation of ecosystem responses to rising atmospheric carbon dioxide. Bioscience 54:731-739

Matamala R, Gonzàlez-Meler MA, Jastrow JD, Norby RJ, Schlesinger WH (2003) Impacts of fine root turnover on forest NPP and soil C sequestration potential. Science 32:1385-1387

Mildner M, Bader MKF, Leuzinger S, Siegwolf RTW, Körner C (2014) Long-term ${ }^{13} \mathrm{C}$ labeling provides evidence for temporal and spatial carbon allocation patterns in mature Picea abies. Oecologia 175:747-762. doi:10.1007/s00442014-2935-5

Moore DJP, Gonzalez-Meler MA, Taneva L, Pippen JS, Kim HS, DeLucia EH (2008) The effect of carbon dioxide enrichment on apparent stem respiration from Pinus taeda L. is confounded by high levels of soil carbon dioxide. Oecologia 158:1-10

Negisi K (1979) Bark respiration rate in stem segments detached from young Pinus densiflora trees in relation to velocity of artificial sap flow. J Jpn For Sci 61:88-93

Norby RJ, Zak DR (2011) Ecological lessons from free-air $\mathrm{CO}_{2}$ enrichment (FACE) experiments. Annu Rev Ecol Evol Syst 42:181-203

Norby RJ, Wullschleger SD, Gunderson CA, Johnson DW, Ceulemans R (1999) Tree responses to rising $\mathrm{CO}_{2}$ in field experiments: implications for the future forest. Plant Cell Environ 22:683-714

Norby RJ, Ledford J, Reilly CD, Miller NE, O’Neill EG (2004) Fine-root production dominates response of a deciduous forest to atmospheric $\mathrm{CO}_{2}$ enrichment. P Natl Acad Sci USA 101:9689-9693
Norby RJ, Warren JM, Iversen CM, Medlyn BE, McMurtrie RE (2010) $\mathrm{CO}_{2}$ enhancement of forest productivity constrained by limited nitrogen availability. P Natl Acad Sci USA 107:19368-19373

Palmroth S, Oren R, McCarthy HR, Johnsen KH, Finzi AC, Butnor JR, Ryan MG, Schlesinger WH (2006) Aboveground sink strength in forests controls the allocation of carbon below ground and its $\mathrm{CO}_{2}$-induced enhancement. Proc Natl Acad Sci USA 103:19362-19367

Pepin S, Körner C (2002) Web-FACE: a new canopy free-air $\mathrm{CO}_{2}$ enrichment system for tall trees in mature forests. Oecologia 133:1-9

Phillips RP, Meier IC, Bernhardt ES, Grandy AS, Wickings K, Finzi AC (2012) Roots and fungi accelerate carbon and nitrogen cycling in forests exposed to elevated $\mathrm{CO}_{2}$. Ecol Lett 15:1042-1049

Pokorný R, Tomášková I, Marek MV (2013) Response of Norway spruce root system to elevated atmospheric $\mathrm{CO}_{2}$ concentration. Acta Physiol Plant 35:1807-1816

Pregitzer KS, Zak DR, Curtis PS, Kubiske ME, Teeri JA, Vogel CS (1995) Atmospheric $\mathrm{CO}_{2}$, soil-nitrogen and turnover of fine roots. New Phytol 129:579-585

Pregitzer KS, Burton AJ, King JS, Zak DR (2008) Soil respiration, root biomass, and root turnover following long-term exposure of northern forests to elevated atmospheric $\mathrm{CO}_{2}$ and tropospheric $\mathrm{O}_{3}$. New Phytol 180:153-161

Pritchard SG, Rogers HH, Davis MA, Van Santen E, Prior SA, Schlesinger WH (2008) Fine root dynamics in a loblolly pine forest are influenced by free-air- $\mathrm{CO}_{2}$-enrichment: a six-year-minirhizotron study. Glob Change Biol 14:588602

R Development Core Team (2011) R: a language and environment for statistical computing. R Foundation for Statistical Computing, Vienna

Raich JW, Schlesinger WH (1992) The global carbon-dioxide flux in soil respiration and its relationship to vegetation and climate. Tellus B 44:81-99

Ryan MG, Waring RH (1992) Maintenance respiration and stand development in a subalpine lodgepole pine forest. Ecology 73:2100-2108

Schleppi P, Bucher-Wallin I, Hagedorn F, Körner C (2012) Increased nitrate availability in the soil of a mixed mature temperate forest subjected to elevated $\mathrm{CO}_{2}$ concentration (canopy FACE). Glob Change Biol 18:757-768

Sigurdsson BD, Medhurst JL, Wallin G, Eggertsson O, Linder S (2013) Growth of mature boreal Norway spruce was not affected by elevated $\mathrm{CO} 2$ and/or air temperature unless nutrient availability was improved. Tree Physiol 33:1192-1205

Smith AR, Lukac M, Bambrick M, Miglietta F, Godbold DL (2013) Tree species diversity interacts with elevated $\mathrm{CO}_{2}$ to induce a greater root system response. Glob Change Biol 19:217-228

Spinnler D, Egh P, Körner C (2002) Four-year growth dynamics of beech-spruce model ecosystems under $\mathrm{CO}_{2}$ enrichment on two different forest soils. Trees-Struct Funct 16:423-436

Teskey RO, McGuire MA (2002) Carbon dioxide transport in xylem causes errors in estimation of rates of respiration in stems and branches of trees. Plant Cell Environ 25:1571-1577

Tingey DT, Lee EH, Waschmann R, Johnson MG, Rygiewicz PT (2006) Does soil $\mathrm{CO}_{2}$ efflux acclimatize to elevated 
temperature and $\mathrm{CO}_{2}$ during long-term treatment of douglas-fir seedlings? New Phytol 170:107-118

Waring RH, Schlesinger WH (1985) Forest ecosystems: concepts and management. Academic Press, London

Zak DR, Pregitzer KS, King JS, Holmes WE (2000) Elevated atmospheric $\mathrm{CO}_{2}$, fine roots and the response of soil microorganisms: a review and hypothesis. New Phytol 147:201-222

Zha TS, Kellomäki S, Wang KY, Ryyppö A (2005) Respiratory responses of scots pine stems to 5 years of exposure to elevated $\mathrm{CO}_{2}$ concentration and temperature. Tree Physiol 25:49-56 